\title{
The Survival of the Secret Treaty: Publicity, Secrecy, and Legality In THE INTERNATIONAL ORDER
}

\author{
By Megan Donaldson*
}

\section{ABSTRACT}

This article offers the first detailed history of the norm of treaty publication as it has evolved over the last century. Drawing on both public debates and archives of foreign ministries, it traces how, and why, secret treaties have persisted, even in liberal democracies. It challenges assumptions of ever-greater transparency over time, and complicates the associations made-by interwar reformers and international lawyers today — between the norm of treaty publication and ideals of legality in the international order.

Concern about "secret diplomacy" in the wake of World War I found its clearest expression in opposition to "secret treaties." Left-leaning and internationalist groups believed that "publicity" of treaties ${ }^{1}$ would advance the control of foreign policy by legislatures and citizens, and help construct a more peaceful international order, governed by law rather than power politics. Article 18 of the Covenant of the League of Nations gave expression to these ideals, by purporting to render the binding force of treaties entered into by any member of the League conditional on their registration by the League Secretariat. Registration in turn entailed publication to the world at large. ${ }^{2}$ Article 18 was thus the first instantiation of a norm of treaty publication in international law (with "treaty" here understood in the general international law sense). ${ }^{3}$ Admittedly, this norm was a relatively narrow one. It guaranteed only the

\footnotetext{
* Junior Research Fellow in the History of International Law, King's College, Cambridge; Lauterpacht Centre for International Law. Email: md718@cam.ac.uk. The work on which this article is based has been enriched by comments and questions in many fora, particularly from Julian Arato, Martti Koskenniemi, Surabhi Ranganathan, Andrew Sanger, Moran Yahav, and the Journal's reviewers. I am grateful also for the assistance of staff at each of the archives. Unless otherwise signaled, translations are my own. A note on archival references: full details of the location of particular archives are given in the first instance in which the relevant archive is mentioned. References are, first, to the location of relevant materials in present-day classifications, with further information in square brackets, where available, identifying original or previous filing details which may assist with retrieval. Document dates are dates of writing or dispatch rather than receipt. All material quoted from archival documents is with original spelling, but any punctuation immediately inside closing quote marks may have been interposed in accordance with AJIL style. Images of all archival documents cited are on file with author. Pursuant to AJIL's recusals policy, Benedict Kingsbury, joint Editor in Chief of this Journal, took no part in consideration or decision-making on this manuscript, as he served as one of the supervisors of the author's doctoral dissertation at NYU Law School and has co-authored other papers with the author.

1 "Publicity" is the term prevailing in the early twentieth century for what would today be captured by "transparency."

${ }^{2}$ Article 18 read: "Every treaty or international engagement entered into hereafter by any Member of the League shall be forthwith registered with the Secretariat and shall as soon as possible be published by it. No such treaty or international engagement shall be binding until so registered."

${ }^{3}$ As will become clear, the definition of "treaty" is crucial to the developments traced here. Unless otherwise indicated, my use reflects the scope of the term as now defined in the Vienna Convention on the Law of Treaties
} 
publication of treaties once made, and did not address the secrecy of the negotiation phase. Nevertheless, it was a major change to law and diplomatic practice. Aspects of Article 18 were carried over into Article 102 of the UN Charter, which in turn was echoed in the Vienna Convention on the Law of Treaties (VCLT). ${ }^{4}$

This article offers the first detailed history of the norm of treaty publication. It traces the emergence of the norm, and struggles over its interpretation and application, through the practice of the United States, Britain, and France. While these three states are not representative of the international community as a whole (neither in the interwar period nor today), their commitment to greater publicity, and influence over modes of diplomacy, makes them a revealing lens on the norm and its limits. The article draws on public debates in legislatures, international organizations, and legal scholarship, but also discussions within foreign ministries and the League of Nations Secretariat. Analysis from these diverse sources offers a clearer picture of the true legal architecture of publicity and secrecy in treaty practice. It suggests how, and why, margins for secrecy have persisted, even in liberal democracies, and draws out for critical scrutiny the relationship between the norm of treaty publication and legality in the international order.

The article challenges the liberal democratic trajectory some might expect, namely evergreater publicity over time. It shows that, while statesmen and officials made real efforts to uphold the publication norm, they also fought to preserve some avenue for making commitments that were both legally binding and secret. In international law, the radical potential of Article 18 of the Covenant - the connection it forged between registration and publication, on one hand, and binding force, on the other-was undone in the early years of the League. Article 102 of the Charter is less ambitious than its predecessor. Domestic law requirements, which arguably play as great a role in driving publication as international requirements, have also left avenues for secrecy, although these have been narrowed and systematized.

Within liberal democracies, the article shows that general attitudes to the norm of publication were driven not only by factors like perceived geopolitical vulnerability, but also national political and legal cultures, and even the bureaucratic organization of the treaty apparatus. Specific efforts to carve out exceptions to the norm of publication, or decisions to flout it, were motivated by diverse considerations: perceived needs to preserve some concrete advantage over military or commercial rivals, to stabilize markets or currencies, and to prevent political opposition from national populations, colonies, or allies; but also to conceal markers of inferiority or subordination in interstate relations, and thus shore up a symbolic economy of interstate equality. For bodies charged with upholding the norm, like the League Secretariat, maintaining the force of Article 18 was important for credibility with internationalist constituencies, but there were countervailing incentives to interpret the provision narrowly in order to avoid confronting — and being seen to be defeated by_-powerful member states.

Many motivations for secrecy on the part of governments and institutions were self-interested and instrumental. However, officials and reformists also thought about secrecy in

(VCLT), opened for signature May 22, 1969, 1155 UNTS 331: a written agreement between states, governed by international law. This is distinct from the meaning of "treaty" and "traitê" in, for example, the U.S. and French Constitutions.

${ }^{4}$ Id. Art. 80. By the time of the drafting of the Vienna Convention, the relevant article was considered to be codifying a customary requirement. See Pierre Klein, Article 80: Registration and Publication of Treaties, in 2 THE Vienna Conventions on the Law of Treaties: A Commentary, 1797, 1798-99 (Olivier Corten \& Pierre Klein eds., 2011). 
principled terms. On occasion, they reconsidered the normative case against secrecy that had been seen as persuasive in 1919. Some came to doubt whether secrecy was always inimical, for example, to peaceful ordering. In some instances, it seemed vital to preserve peaceful relations.

The doubts of contemporaries suggest enduring questions about whether and how the norm of treaty publication favors ends like democracy, peace, and legality. ${ }^{5}$ This article probes, in particular, the relationship between publicity and legality in the international order. In doing so, it gives a sense of the complex empirical terrain in which questions about democracy and peace, too, would have to be pursued.

Actors concerned with publicity articulated different dimensions of the relationship between publicity and legality. Simplified for the sake of analysis, much of the discussion about publicity posited, first, a basic conceptual or normative connection to legality. This could take the form of assertions that legal relations and obligations were inherently public, or that they ought to be public. Second, there was an expectation that the norm of treaty publication would strengthen the role of law in the international order more generally (for example, by improving the dissemination and coherence of the law itself, fostering a commitment on the part of governments to following the law, or levelling out power imbalances between states and vindicating sovereign equality). This combined a general normative sensibility with a number of very condensed assumptions about the effects of publication or secrecy in particular contexts. Finally, there was confidence in law as a means of entrenching the norm of publication. This article shows that each of these stylized dimensions of the relationship between publicity and legality proved more complex-empirically and conceptually_than it had seemed in 1919.

The article intersects with doctrinal scholarship on the law of treaties and emergent research on why states craft interstate commitments in particular ways. However, doctrinal scholarship — cited very sparingly here-often concentrates on problems of classification, like the definition of a treaty ${ }^{6}$ and distinctions between legally binding "treaties" and "gentlemen's" or "non-binding" agreements; ${ }^{7}$ or on questions which flow from classification of texts, like the role of ancillary texts in interpretation. ${ }^{8}$ By contrast, emergent research on why states make agreements in the form they do largely brackets these questions. ${ }^{9}$ This article

\footnotetext{
${ }^{5}$ For a recent defense of limited secrecy in international commitments, both legal and political, see, e.g., Ashley S. Deeks, A (Qualified) Defense of Secret Agreements, 49 ARIZ. ST. L.J. 713 (2017).

${ }^{6}$ See, e.g., Malgosia Fitzmaurice, The Identification and Character of Treaties and Treaty Obligations Between States in International Law, 73 BRIT. Y.B. INT'L L. 141 (2003).

${ }^{7}$ See, e.g., Christine Chinkin, A Mirage in the Sand? Distinguishing Binding and Non-binding Relations Between States, 10 Leiden J. Int'L L. 223 (1997); Jan Klabbers, The Concept of a Treaty in International LaW (1996); Anthony Aust, Modern Treaty LaW and Practice 46-49 (3d ed. 2013); Jan Klabbers, Not Re-visiting the Concept of Treaty, in 40 Years of the Vienna Convention on the LaW of Treaties 29 (Alexander Orakhelashvili \& Sarah Williams eds., 2010).

${ }^{8}$ See, e.g., Paul Reuter, Traités et transactions. Reflexions sur l'identification de certains engagements conventionnels, in Le Droit international à L'Heure de SA Codification. Études en l'Honneur de Roberto Ago I, at 399 (1987). What I call "ancillary texts" are texts which, taken together with a primary text, form a sort of transactional package, although their relation to the primary text may be ambiguous. They may be, but are not necessarily, part of the travaux préparatoires, or analyzed as "interpretive declarations" or "understandings."

9 See, e.g., Charles Lipson, Why Are Some International Agreements Informal?, 45 INT'L OrG. 495 (1991); Kenneth W. Abbott \& Duncan Snidal, Hard and Soft Law in International Governance, 54 INT'L OrG. 421 (2000); Kal Raustiala, Form and Substance in International Agreements, 99 AJIL 581 (2005). For analyses which grapple with law and politics together, see, e.g., Surabhi Ranganathan, Strategically Created Treaty Conflicts and the Politics of International Law (2014); Grégoire Mallard, Fallout: Nuclear Diplomacy in an Age of Global Fracture (2014).
} 
puts the law at the heart of the inquiry. Unlike doctrinal scholarship, though, it is not aimed at reaching its own classification of the texts considered. Rather, it probes what interlocutors understood themselves to be doing in drafting or handling texts in particular ways.

Attention to these features of treaty practice, often side-lined in doctrinal accounts, gives a much richer picture of the true architecture of publicity and secrecy. It reveals the possibilities created by the interplay of the law of treaties with diplomatic crafts of drafting, and the management of texts within foreign ministry bureaucracies. It suggests a more expansive canvas for states crafting their commitments than can be captured in many studies of state behavior. Governments are not only choosing between treaties and non-binding agreements, for example, but crafting complexes of different texts, making choices about presentation and emphasis which are difficult to capture in quantitative ways. Officials are sometimes uncertain about the status of particular texts, in disagreement with each other, or consciously shaping textual forms to preserve ambiguity about legal status. Finally, close attention to the crafting of texts and the negotiation of the bounds of the category of treaty brings to the fore some paradoxical aspects of secrecy in the international legal order. Secret treaties, by their nature, will never enjoy many avenues for rhetorical or institutional enforcement typically associated with legally binding commitments. They might even thus reflect a faith in legal obligation alone to shape staff behavior. Conversely, however, some secret treaties purport to commit states to actions which may violate international law, calling broader commitments to legality into question.

The article begins with a brief overview of the pre-World War I (WWI) landscape (Part I). It then traces the emergence of Article 18, and the tacit qualification of this provision in the early years of the League's existence (Part II), before addressing interwar confrontations with a comprehensive publication norm in national public law and practice (Part III). While interwar developments are considered in detail, as they shaped approaches taken after World War II (WWII), the treatment of national practice is necessarily selective, focusing on examples which illustrate the range of areas in which secrecy was sought, the repertoire of techniques used, and particular turning points in national approaches. The article then considers the transformation of the treaty publication norm after WWII, a period for which the archival material becomes scarcer (Part IV). It sketches the evolution of techniques of secrecy, and changing legal approaches to its management, from WWII to the present (Part V), before offering a snapshot of the secret treaty today (Part VI). Finally, it summarizes developments over the last century, and what they reveal about the empirical landscape in which to consider the relationship of publicity to democracy, peace, and legality in the future (Part VII).

\section{Secret Treaties on the Eve of World War I}

Prior to WWI, the secret treaty was a recognized, if criticized, legal instrument. International law imposed no requirement that treaties be published. Such a requirement, if it existed at all, stemmed from national laws or practices concerning legislative knowledge or approval of treaties. There was no consensus on whether a failure to adhere to domestic law respecting treaty-making affected the validity of a treaty under international law. ${ }^{10}$

\footnotetext{
${ }^{10}$ See, e.g., Charles Cheney Hyde, Agreements of the United States Other Than Treaties, 17 GreEn Bag 229, 229 (1905); L. OpPenHeim, 1 InTERNATIONAL LAW: A Treatise 536-37 (1905); and scholarship summarized in LouIS Michon, Les Traités internationaux devant les Chambres 416-20 (1901).
} 
Of the three states examined here, the United States was the only one with an ostensibly comprehensive requirement for legislative approval prior to ratification, in the form of the requirement for Senate advice and consent for all "treaties" within the meaning of Article II of the Constitution. Once ratified, at least, these texts would be published. Yet, as is well-known, U.S. practice recognized a range of "executive agreements" made without Senate advice and consent. ${ }^{11}$ While most executive agreements were published in one form or another, ${ }^{12}$ some did remain secret, and it was therefore possible to make secret, and legally binding, agreements. However, scholars in the early twentieth century included in lists of "executive agreements" a number of "gentleman's agreements" or "diplomatic agreements" which they considered binding only on the president who made them (and successors, if they did not repudiate the agreements), rather than on the state. ${ }^{13}$ Some of the more notorious instances of secret texts fell within this category, including the 1907-08 "gentleman's agreement," under which the Japanese Government would limit Japanese migration to the United States. ${ }^{14}$ The "secret treaty" in the sense of a text that was both unambiguously binding on the state under international law, and secret, was therefore marginal to U.S. practice, if it was used at all.

In Britain, the Crown alone had the authority to make and ratify treaties. If a treaty was not of a nature to require any immediate change in the existing law, or further legislative steps for its implementation, there was no requirement that its existence be disclosed to the Parliament or to the public at large. Treaties were customarily published as parliamentary papers, but this publication was not required by law. Accordingly, secret treaties were a feature of British practice, although they were used relatively sparingly. ${ }^{15}$

In France, the president of the Republic, empowered to negotiate and ratify treaties, was required to "give information of their contents" to the legislature "[a]s soon as the interest and safety of the State shall permit." 16 This language, taken alone, permitted indefinite secrecy of treaties once made, unless they required promulgation in order to function in domestic law,

${ }^{11}$ Constitutional authority for which was grounded in, for example, powers delegated by Congress to make agreements on certain matters; or the president's own powers (as commander in chief, as the sole organ of foreign negotiation, etc.). See, e.g., Hyde, supra note 10; John Bassett Moore, Treaties and Executive Agreements, 20 PoL. Sci. Q. 385 (1905); Samuel B. Crandall, Treaties, Their Making and Enforcement 102-40 (2d ed. 1916).

12 The Statutes at Large were intended to contain "agreements" as well as treaties made with Senate advice and consent. Printing Act of 1895, ch. 23, 53d Cong., \$73, 28 Stat. 601.

${ }^{13}$ See, e.g., Quincy Wright, The Control of the Foreign Relations of the United States: The Relative Rights, Duties, and Responsibilities of the President, of the Senate and the House, and of the Judiciary, in Theory and in Practice, 60 Proc. Am. Phil. Soc’y 99, 323, 331 (1921); William Hays Simpson, Legal Aspects of Executive Agreements, 24 Iowa L. Rev. 67, 78 (1938).

${ }^{14}$ This "agreement" was in fact contained in a long series of diplomatic correspondence: see subsequent discussion in Memorandum by the Secretary of State of a Conversation with the Japanese Ambassador (Hanihara), Mar. 27, 1924, in 2 Papers Relating to the Foreign Relations of the United States, 1924, at 337-38 (1939). The American government had initially wished the agreement to be a Senate-approved treaty, but this would have exposed the Japanese government to domestic criticism for surrendering rights under an earlier treaty, and acquiescing to racially-driven resentment. RAYMOND A. Esthus, THEODORE RoOSEvelT AND JAPAN 158-64 (1967). The agreement did ultimately operate beyond the terms in office of the parties to the correspondence.

${ }^{15}$ An 1878 British Foreign Office (FO) memorandum lists only ten or so instances of secret treaties of alliance concluded by Britain since the beginning of the nineteenth century. Oakes, Instances in Which Great Britain Has Been Party to Secret Treaties of Alliance, Subsidy, FO 881/3665 (July 12, 1878). There were, however, further secret treaties other than alliances.

${ }^{16}$ Loi constitutionnelle du 16 juillet 1875 sur les rapports des pouvoirs publics, Art. 8, as translated in HeNRY C. Lockwood, Constitutional History of France 406, 407 (1890). 
or entailed legislation for their implementation. However, as in many other Continental European constitutions, certain treaties ("of peace, of commerce, ... which involve the finances of the State, ... which refer to the condition of persons, [or] to the rights of property of Frenchmen in foreign countries") were "not final" until voted on by the two Chambres, and no cession, exchange, or annexation of territory could take place except by virtue of a law. ${ }^{17}$ This required certain categories of treaty to be laid before the legislature and thus subjected to formal or de facto publicity. At the same time, many of the most consequential "political" treaties, particularly treaties of alliance, were generally not considered to fall within the categories requiring legislative approval, and could thus be kept secret until "the interest and safety of the State ... permit[ted]" their communication. ${ }^{18}$

Although national law and practice sometimes used "treaty" in a narrow sense, and made distinctions between different types of treaties, the orthodox doctrinal position under international law was, by WWI, that there was a single juridical category of treaty:

International compacts which take the form of written contracts are sometimes termed not only agreements or treaties, but acts, declarations, protocols, and the like. But there is no essential difference between them, and their binding force upon the contracting parties is the same, whatever be their name. ${ }^{19}$

This posture sought to impose a formal coherence on what remained a very rich repertoire of forms for the making of promises between states. Variations in nomenclature reflected the fact that older writings on the law of nations had assumed a repertoire of different kinds of agreement, rather than a unitary category of treaty. ${ }^{20}$ Such variations were still used as rough indicia of relative importance and solemnity, and some authors posited distinctions between texts of different kinds which, if they did not indicate a distinction in the nature or degree of legal force, at least marked differences in the circumstances in which the obligations would come to an end. There was a strong sense that the diversity of forms and nomenclature mattered, although it was difficult to say precisely how. ${ }^{21}$

The form of written agreements was not itself regulated by law, but by a diplomatic craft of drafting. Typically, important "political" clauses would be in a principal text, and signed by more senior figures or with greater solemnity, whereas more trivial or detailed clauses could be relegated to an ancillary text, sometimes signed separately by lesser figures (without

\section{${ }^{17} I d$.}

${ }^{18}$ Albert Dauzat, La Convention et les traités secrets, LXXII Revue PolitiQue et PARLEMENTAIRE 371, 379 (1912); Gaston Jèze, Le Pouvoir de conclure les traités internationaux, et les traités secrets, XXIX REVUE DU DROIT PUBLIC ET DE LA SCIENCE POLITIQUE EN FranCE ET A L'ETRANGER 313 (1912).

${ }^{19}$ See, e.g., L. Oppenheim, 1 International Law: A Treatise 664-65 (Ronald F. Roxburgh ed., 3d ed. 1920) (emphasis in original; footnote in original omitted).

${ }^{20}$ Note also distinctions between traité-contrat and traité-loi; and between mere contracts (involving disparate wills but agreement on a shared external end) and Vereinbarung (involving a genuine fusion of wills), with only the latter capable of creating law rather than subjective rights. Heinrich Triepel, Droit inTernational et Droit INTERNE 49-61 (René Brunet trans., 1920); Arnold D. McNair, The Functions and Differing Legal Character of Treaties, 11 BRIT. Y.B. INT'L L. 100, 105-16 (1930).

${ }^{21}$ E.g., Jules Basdevant queried whether the distinction between "treaties" (i.e., here, agreements concluded with the intervention of the supreme treaty-making authority within a state) and agreements made in some other form was relevant to the obligatory character of the texts. Jules Basdevant, $\mathrm{La}$ Conclusion et la rédaction des traités et des instruments diplomatiques autres que les traités, 15 RECUEIL DES COURS 535, 545 (1926). This hint is not further explored. See also McNair, supra note 20. 
necessarily implying any lesser degree of legal force). These practices responded to practical and aesthetic considerations, but were also amenable to differentiation between public and secret texts. Secret clauses or "réserves" of the kind satirized earlier by Kant, ${ }^{22}$ and prohibited by some European constitutions, sometimes went as far as contradicting commitments made in the principal (public) text, but there were also less flagrantly contradictory ancillary texts, of uncertain status, which merely gave a different complexion to the principal text. These features of treaty practice - the diversity of forms and terms, and the centrality of a flexible craft of drafting - would prove major obstacles to initiatives for greater publicity.

The use of secret treaties and ancillary texts had already been an object of political contestation, albeit with quite different political inflections, in earlier moments of tension over the relation between the domestic political order and national and imperial foreign policy. ${ }^{23}$ In the late nineteenth century, European jurists, motivated by a need to systematize the material basis of international law, proposed a comprehensive international treaty collection, but conceded that this might include only treaties the publication of which would not be precluded "by reasons of state or by political expediency [convenances politiques]." ${ }^{4}$ In the early twentieth century, gradual revelations of inter-imperial dealings shaped by secret clauses and ancillary texts, associated with mounting tension between France and Germany, prompted more far-reaching attacks on secrecy from across the political spectrum. In France, revelations in 1911 that Germany's non-interference in Morocco had been purchased with the (undisclosed) cession of parts of the French Congo led to the fall of the government and harsh criticism in the Chambres and press. The pro-colonial lobby was most upset about the substance of the bargain, but on the left there were demands for constitutional change to preclude secret treaties. While this failed, the new government undertook to submit foreign policy, insofar as possible, to the Chambres and to public opinion, and to take a broad view of the categories of treaty requiring approval. ${ }^{25}$ Revelations that the British had been apprised of a secret Franco-Spanish treaty gave rise to attacks in Parliament on the perceived underhandedness of this diplomacy.

Spanning different substantive and party-political debates, one can discern a cluster of persistent and related concerns in the early twentieth century. Secret treaties were seen as an autocratic anachronism, out of place in the democratic state insofar as they undermined the proper role of legislatures or, for some thinkers, citizens themselves, in monitoring foreign policy. Secret treaties were seen as inimical to peace, whether because they allowed states to make offensive alliances, or because they fostered an atmosphere of suspicion and apprehension, thereby rendering more likely the outbreak of conflict. This apprehension and resulting

\footnotetext{
${ }^{22}$ Immanuel Kant, Perpetual Peace, in Kant: Political Writings 93, 94, 114-15 (Hans Reiss ed., H. B. Nisbet trans., $2 \mathrm{~d}$ ed. 1991).

${ }^{23}$ Particularly the American and French Revolutions, and in nineteenth-century British debates over free trade. This and following paragraphs condense material from Megan Donaldson, From Secret Diplomacy to Diplomatic Secrecy: Secrecy and Publicity in the International Legal Order c. 1919-1950 (2016) (unpublished JSD dissertation, New York University School of Law) (on file with author).

${ }^{24}$ Institut de Droit international, Voeu concernant la publication des traités (Sept. 11, 1885), available at http:// www.idi-iil.org/app/uploads/2017/06/1885_brux_01_fr.pdf. An 1891 proposal for the formation of an International Union to oversee publication of treaties petered out. DenYs Peter Myers, Manual of Collections of Treaties and of Collections Relating to Treaties 600-03 (1922).

25 See Jèze, supra note 18, at 318, 320-21. A demand for constitutional revision of Article 8 failed (146 votes in the Chambre des Députés and 372 against). Id. at 319.
} 
possibility of violence in turn favored brute power politics, and was thought to hinder the construction of a law-governed interstate system.

\section{The Formulation and Qualification of Article 18, c. 1919-1923}

\section{The Early Life of Article 18}

World War I threw into sharp relief the power of treaties, public or secret, in the international order. The discovery in 1914 of the extent of British commitments to France was part of the impetus for the formation of the Union of Democratic Control, a group aiming to increase parliamentary control of foreign policy. The Bolsheviks' 1917 release of wartime secret treaties found in tsarist archives cast secret treaties in a particularly nefarious light, and sharpened preexisting concerns about their effects. ${ }^{26}$ Criticisms of secret diplomacy, while particularly strong on the left, ${ }^{27}$ had some appeal across the political spectrum, especially in Britain and the United States. ${ }^{28}$ These criticisms were both reflected and amplified by Woodrow Wilson's embrace of "open covenants" and "diplomacy [that would] proceed always frankly and in the public view." 29

Agendas for reform covered quite a range of positions, from demands that negotiations themselves should be public to demands for publication of final treaty texts, and from a focus on empowering citizens directly in foreign policy, to strengthening legislatures (or committees of experts within them) to act on behalf of citizens. The publication of treaties once made was a relatively minimalist, and seemingly uncontroversial, goal. It had been proposed by various pacifist and internationalist groups during WWI, but the text that would become Article 18 was ultimately introduced into the draft Covenant by American figures. ${ }^{30} \mathrm{It}$ attracted no debate in the League of Nations Commission, the body responsible for the drafting of the Covenant. This is perhaps unsurprising, given the sheer number of major issues then under discussion, but it also indicates that Article 18 was consonant with aspirations for the reform of diplomacy that negotiators either accepted, or found difficult to oppose, at least in public.

In its final form, Article 18 read:

\footnotetext{
${ }^{26}$ See, e.g., publication of English texts under the aegis of the Union of Democratic Control. THE SECRET Treaties and Understandings: Text of the Available Documents (F. Seymour Cocks ed., 1917).

${ }^{27}$ See, e.g., Statement of War Aims as Adopted at a Joint Conference of the Societies Affiliated with the British Trades Union Congress and the British Labour Party [Dec. 28, 1917], reproduced in BRITISH LABOR AND THE WAR: Reconstructors for a New World 343 (Paul U. Kellogg \& Arthur Gleason eds., 1919).

28 See Arno Mayer, Political Origins of the New Diplomacy, 1917-1918 (1959); Peter Jackson, French Security and a British 'Continental Commitment' After the First World War: A Reassessment, 126 EngLisH Hist. Rev. 345, 347-49 (2011); George Bernard Noble, Policies and Opinions at Paris, 1919: Wilsonian Diplomacy, the Versailles Peace, and French Public Opinion 301-52 (1935) (on the shifting importance given to "open covenants" in French press debates).

${ }^{29}$ Woodrow Wilson, The Terms of Peace [Address to both Houses of Congress, Jan. 8, 1918], in IN OUR FIRST YEAR of War: Messages and Addresses to the Congress and the People March 5, 1917, to April 6, 1918, at 150, 156 (1918).

${ }^{30}$ David Hunter Miller (legal adviser to the American Commission to Negotiate Peace) introduced a requirement for publicity of treaties; Robert Lansing (U.S. secretary of state) added the component of registration with the Secretariat (although Alfred Zimmern, then serving in the Political Intelligence department of the FO, had proposed something similar); and Wilson himself contributed the provision that no treaty should be binding unless registered. David Hunter Miller, 1 The Drafting of the Covenant 19, 29, 49, 198 (1928).
} 
Every treaty or international engagement entered into hereafter by any Member of the League shall be forthwith registered with the Secretariat and shall as soon as possible be published by it. No such treaty or international engagement shall be binding until so registered.

A Memorandum of May 1920, drafted by the League Secretariat's Legal Section and the secretary-general, reflected what Article 18 was intended to achieve:

Publicity has for a long time been considered as a source of moral strength in the administration of National Law. It should equally strengthen the laws and engagements which exist between nations. It will promote public control. It will awaken public interest. It will remove causes for distrust and conflict [and] ... enable the League ... to extend a moral sanction to the contractual obligations of its Members. It will, moreover, contribute to the formation of a clear and indisputable system of International Law. ${ }^{31}$

On paper, Article 18 marked a shift from a pre-war world, in which the secret treaty was criticized but legally permitted, to a post-WWI order in which such treaties would be abolished, at least for League members. The role accorded to the Secretariat in registering treaties sat alongside other provisions which hinted at a larger evolution toward a more collective, institutionalized legal order. Article 19 envisaged that " $[\mathrm{t}]$ he Assembly [would] from time to time advise the reconsideration by Members of the League of treaties which have become inapplicable and the consideration of international conditions whose continuance might endanger the peace of the world." 32 Article 20 provided that members "agree that this Covenant is accepted as abrogating all obligations or understandings inter se which are inconsistent with the terms thereof, and solemnly undertake that they will not hereafter enter into any engagements inconsistent with the terms thereof."

The 1920 Secretariat Memorandum offered an expansive, antiformalist definition of the phrase "every treaty or international engagement" in Article 18. This was said to encompass "not only every formal Treaty of whatsoever character and every International Convention, but also any other International Engagement or Act by which nations or their Governments intend to establish legal obligations between themselves and another State, Nation or Government."33

The Memorandum gave full effect to a reading of the Covenant in which registration, and thence publication, was a precondition of legal force. To this end, it proposed that treaties be submitted for registration, at the latest, by the date on which the parties considered them to come into force. ${ }^{34}$

\footnotetext{
${ }^{31}$ The Registration and Publication of Treaties as Prescribed Under Article 18 of the Covenant of the League of Nations, as published in 1 LNTS 9, para. 1 (emphasis in original) [hereinafter 1920 Secretariat Memorandum]. See also, e.g., M. F. LaRnaude, La Société des Nations 39 (1920).

${ }^{32}$ Due to fears that a robust reading might open the path to revision of the peace treaties, Article 19 was given a relatively narrow interpretation, and none of the efforts to invoke the provision came to fruition. HERMANN Mosler, The International Society as a Legal Community 289-90 (1980).

331920 Secretariat Memorandum, supra note 31, at para. 3.

${ }^{34}$ Id., para. 5. The Memorandum permitted treaties to be submitted for registration by one party alone, provided that the text had been finally agreed between the parties (para. 8), and suggested that parties should deposit "a textual and complete copy [of the treaty or engagement] with all appurtenant declarations, protocols, ratifications, etc. ... with an authentic statement that this text represents the full contents of the Treaty or Engagement" (para. 6). British officials, apparently not aware of the arrangements in the 1920 Secretariat Memorandum, circulated to states alternative proposals, namely that bilateral treaties be registered by both parties jointly, but multilateral treaties be registered only by the government of the state in which the treaty was signed. Circular Curzon to representatives abroad, Sept. 20, 1920, FO 372/1409 [File No. 208994] ["FO" in archival references denotes
} 
While delegates on the Council approved the 1920 Secretariat Memorandum, closed-door discussions revealed concerns about the full import of Article 18. The delegates agreed between themselves on support for the "grand moral idea" that peoples must not be engaged by governments without their knowledge, and Léon Bourgeois (France) expressed resistance to carving out exceptions to Article 18. However, he joined with Arthur Balfour (British Empire) in arguing that members retained a capacity to conclude treaties that would not be registered-but would nevertheless place the signatories under some moral obligation, which the League might uphold. Dr. van Hamel, the Dutch Director of the Legal Section, was recorded as stating that, under the Covenant, members of the League would not be bound by an unregistered treaty - but that the parties could nevertheless consider themselves bound in some way inter se. ${ }^{35}$ These ominous divergences of opinion about Article 18 were not, however, probed further at this time.

\section{First Tests: French Military Accord and British Financial Arrangements}

The first real test of Article 18 was a Franco-Belgian military "accord" of $1920 .{ }^{36}$ At this time, Franco-Belgian military arrangements were controversial within Belgium, where socialist and Flemish deputies tended to oppose arrangements they perceived as likely to render the state dependent on France. It was thus not only military sensitivity, but likely political opposition, which shaped early thinking about the final form of the commitments. After early drafts of the proposed accord had been prepared by military figures, the Belgian foreign ministry contemplated splitting the text into a "political" act, which could be submitted to the Chambres (in accordance with Belgian constitutional clauses requiring legislative approval of certain treaties, and arrangements for foreign troop movements) and submitted to the League Secretariat for registration, and a separate act for the detailed military arrangements, which could be kept secret. The idea of a substantive "political" text was abandoned out of a fear that any treaty involving France alone, rather than France and Britain together, would still attract opposition in Belgium. ${ }^{37}$

The initial "military accord" had not dealt with matters like the casus foederis, and circumstances in which the accord could be brought to an end, but it still had significant political implications. In particular, by requiring Belgium to take action in the event of any German mobilization, it left Belgium potentially implicated in a war between Germany and Eastern European countries; and by envisaging a concerted defense, including along the frontier with

National Archives (UK), Foreign Office papers (held at Kew)]. The Secretariat, concerned that placing the onus on the headquarters government in this way would have made registration contingent on the diligence of a single government, reasserted the authority of the Council-approved Memorandum. Drummond to Hankey, Oct. 1, 1920, FO 372/1409 [T11337/9008/350].

35 "Questions Connected with the Registration of Treaties which Arose during the Council Meeting at Rome, in May, 1920," enclosed with Van Hamel to Hurst and others, May 6, 1921, League of Nations Archives, Registry Files, R1220 [17/12549/69] ["LNA R" in archival references denotes League of Nations Archives, Registry Files (held in Geneva)].

36 “Accord" is probably best translated as "agreement," but I follow most contemporary English-language sources in simply adopting the French term.

37 J. E. Helmreich, Convention politique ou accord militaire? La Négociation de l'accord franco-belge de 1920, 159 GuERRES MONDIALES ET CONFLITS CONTEMPORAINS 21, 25-26 (1990); J. E. Helmreich, The Negotiation of the Franco-Belgian Military Accord of 1920, 3 French Historical Studies 360, 374 (1964). Helmreich worked from the Belgian archives. My research in the archives of the French foreign ministry, while likely not capturing all military deliberations, captures the French approach to the accord's legal form. 
Luxembourg, it ran counter to Luxembourg's nominal independence. ${ }^{38}$ A version of this text was signed on July 29, 1920 by Marshal Foch (president of the French Superior Council of War) and General Maglinse (chief of the Belgian General Staff). It was thought necessary for governments to exchange letters approving this accord, which would be published, although this does not appear to have been based on a theory that the military accord otherwise lacked legal force. ${ }^{39}$

The Belgians subsequently proposed amendments to the military accord, and at this point the Belgian ministry of foreign affairs proposed that the public exchange of letters be expanded to cover some aspects of the abandoned "political" accord, and laid before the legislature, without being a treaty requiring approval. ${ }^{40} \mathrm{~A}$ second version of the military accord thus replaced the initial version (adding, inter alia, a new undertaking by the French to defend the Belgian coast, which was politically controversial insofar as it foreshadowed FrancoBelgian military action without British involvement). ${ }^{41}$ Belgian and French foreign ministers exchanged public letters approving the accord. ${ }^{42}$

When the letters were laid before the Belgian legislature in October 1920, there were demands for the military accord to be published. ${ }^{43}$ The French Ministère des Affaires Etrangères (MAE) expressed concern that, when the letters were submitted for registration, the League Secretariat would immediately demand the military accord. ${ }^{44}$ In Britain, questions were asked in Parliament about whether Britain would press for registration. ${ }^{45}$ Britain was probably the only other power influential enough to press France to submit the accord, and the Foreign Office (FO) was well aware that if other powers withheld politically significant texts as France was apparently doing, "the whole principle of registration will fall to pieces." 46 However, Britain had declined to give security guarantees sought by France, and found it difficult politically to do anything which might be perceived as weakening fallback Franco-Belgian arrangements. Moreover, the British Treasury had become concerned, for its part, about registration of various financial dealings.

Internally, French and British officials began wondering if Article 18 might be limited in some way. French officials argued that the military accord should be seen "not as an international treaty, but as an arrangement between general staffs, subject to variations in accordance with military necessity," and impossible to divulge without compromising national defense. ${ }^{47}$ The British Treasury suggested that "an endeavour should be made to limit the scope" of Article

${ }^{38}$ Helmreich, Convention politique, supra note 37 , at 24

${ }^{39}$ Basdevant observes that "military conventions" bind states though not embodied in "diplomatic" instruments. Basdevant, supra note 21, at 626.

${ }^{40}$ Helmreich, Convention politique, supra note 37 , at 29.

41 This accord is now reproduced in 2 Documents Diplomatiques Français 1920, at 566 (1999). On the contents, see Helmreich, Convention politique, supra note 37, at 28; Helmreich, Negotiation, supra note 37, at 377.

${ }^{42}$ For the final text of the letters, see Exchange of Letters of 10 and 15 September, 1920, Between the Belgian and French Governments, Concerning the Approval of the Franco-Belgian Military Understanding of September 7, 1920, 2 LNTS 128.

${ }^{43}$ Helmreich, Negotiation, supra note 37, at 377.

${ }^{44}$ Note pour Monsieur Berthelot, Oct. 18, 1920, MAE CPC 73 [Z126/10] ["MAE CPC" in archival references denotes Archives diplomatiques (France), "Correspondance politique et commerciale" series (held at La Courneuve)].

${ }^{45}$ House of Commons Debates, $5^{\text {Th }}$ Ser., vol. 133, col. 1374W (Oct. 25, 1920), cols. 1549-50 (Oct. 26, 1920); vol. 134, cols. 35-36 (Nov. 1, 1920) [hereinafter HC Dев.].

${ }^{46}$ Minute Mounsey, Sept. 15, 1920, FO 372/1409 [T10214/9008/350].

${ }^{47}$ MAE to Embassy, Brussels (with handwritten amendments), Oct. 24, 1920, MAE CPC 73 [Z126/10]. 
18 to "International Treaties and Agreements of first class importance." ${ }^{48}$ The FO dismissed as "useless" any endeavour to limit Article 18 in this sense, ${ }^{49}$ and rejected also an exception for "arrangements of a purely commercial or financial character," which encompassed exactly the treaties regarding commerce and preferential trading rights that Britain was keen to see states publish. ${ }^{50}$ At the same time, the FO found it difficult to articulate any principled approach:

Possibly the League [Secretariat] might wink at the non-registration of financial agreements of the kind indicated in the Treasury letter; but they cannot logically wink at the non-registration of an instrument [like the Franco-Belgian military accord] which is not so very far removed from an offensive and defensive alliance. There will be a hue and cry about "secret diplomacy" again ... . I confess I do not see any formula which will meet with approval, but "agreements of a technical nature" might be stretched to cover anything. ${ }^{51}$

Senior political figures were divided. The foreign secretary, Curzon, thought it was impractical to expect military details to be published. ${ }^{52}$ On the other hand, Robert Cecil (a Conservative politician, and a major supporter of the League, then serving as a delegate for South Africa in the League Assembly) saw the application of Article 18 to the military accord as a crucial point of principle. Drafters of the Covenant, Cecil argued, had hoped that "one of [Article 18's] most valuable results would be to hinder secret military preparations [which] have been in the past a prolific source of suspicion + counter-preparations leading ultimately to war." 53

For Balfour, who was to represent Britain at the upcoming League meetings,

[If] we are to interpret [Article 18] as meaning that every nation is at liberty to make what secret arrangement it likes ..., provided it does not ask the League to defend that arrangement until it has been published; [then] Article 18 does really nothing to put an end to socalled secret diplomacy. If, on the other hand, Article 18 is to be interpreted as meaning that [withholding a treaty] is an offence against the provisions of the Covenant . . . then ... the refusal of France and Belgium to comply with the Covenant brings us face to face with a very serious international issue. ${ }^{54}$

In the face of this dilemma, Balfour wondered whether, if the Council asked the French and Belgian governments to register the treaty "in its broad outline," and to give formal assurances that it was purely defensive, the Council might then decide that the military details need not be submitted for registration. ${ }^{55}$

Hurst noted that the Covenant's drafters had probably intended to oblige states to register all treaties - but that they may not have considered "the inconvenience which a strict construction of the Article would entail, or the difficulty of enforcing it." Having regard to these

\footnotetext{
${ }^{48}$ Blackett [Treasury] to Under-Secretary of State, Sept. 7, 1920, FO 372/1409 [T10214/9008/350].

${ }^{49}$ Minute J. Balfour, Oct. 1, 1920, FO 371/5455 [W493/32/4].

${ }^{50}$ Blackett [Treasury] to Under-Secretary of State, Sept. 29, 1920; Minute Crowe, Oct. 3, 1920; both FO $372 /$ 1409 [T11090/9008/350].

${ }^{51}$ Minute Villiers, Oct. 1, 1920, FO 371/5455 [W493/32/4] (emphasis added).

52 Curzon to Cecil, Oct. 5, 1920, FO 371/5455 [W493/32/4].

53 Cecil to Curzon, Oct. 6, 1920, FO 371/5455 [W857/32/4].

${ }^{54}$ Memo Balfour to Hurst, Oct. 20, 1920, FO 372/1410 [T12369/9008/350].

${ }^{55} \mathrm{Id}$.
} 
matters, and the wording of the French version, ${ }^{56}$ he suggested Balfour's approach would be acceptable. ${ }^{57}$ This reflected the British position throughout the ensuing debates: the FO realized the systemic importance of Article 18, yet could generate no really principled limitations to it, and ended up making pragmatic efforts to tailor the provision to national needs.

The French delegation to the League was instructed to press at Geneva for an interpretation of Article 18 as covering any "convention, treaty or accord constituting . . . a state-to-state engagement, that is to say, of a diplomatic order," but not "contracts of a commercial or administrative or technical order." 58 Britain did not commit to supporting precisely this position, but the two leading League members agreed prior to the League session that Article 18 could be qualified in some way, ${ }^{59}$ even if British instructions still urged delegates to "avoid the impression of encouraging 'secret diplomacy."'60

\section{Deliberations Within the League, Jurisprudence and Scholarship}

The Secretariat was in a delicate position. On one hand, the need to demonstrate that the League was useful to French security rendered it unthinkable to press for registration of what France refused to publish. On the other hand, the norm of publication was popular and highly symbolic. After the Versailles settlement, which was seen by many internationalists as compromising principles of self-determination, and burdening Germany with a victors' peace, Article 18 was one of the few idealistic provisions carried intact into the League order. The Secretariat was keen to maintain the faith of internationalist supporters by upholding the provision. The Secretariat worked assiduously behind the scenes to hasten submission of treaties, ${ }^{61}$ and Juan Teixidor y Sanchez, the Secretariat official principally responsible for treaty registration, was frustrated to see " $[t]$ he Press . . . airing opinions of all kinds on the influence that the coming into force of such a [c]onvention, without being registered, or being half-registered . . . may have on the maintenance of the Covenant." 62

Teixidor rationalized that the exchange of letters could be registered and the "technical" (military) text withheld, analogizing the situation to other treaties involving both an agreement between countries and a regulation established by technicians for its execution. However, this analogy did not capture the nature of the texts in issue, and even Teixidor himself noted the need to ensure that the technical regulation did not run counter to the provisions of the League Covenant (something which sat uneasily with registering only the exchange of letters). ${ }^{63}$

\footnotetext{
${ }^{56}$ See infra note 75 (the French text put the emphasis on the Secretariat's duty to register, rather than the members' duty to register with the Secretariat).

${ }^{57}$ Memo Hurst to Balfour, Registration of Treaties Under Article 18 of the Pact, undated [c. Oct. 1920], FO 372/1410 [T12369/9008/350].

${ }^{58}$ Note, Enregistrement des traités, Nov. 11, 1920, MAE SDN 71 ["MAE SDN" in archival references denotes Archives diplomatiques (France), "Société des Nations" series (held at La Courneuve)].

59 Tufton to [MAE], Nov. 11, 1920, MAE SDN 71. See also minute Hurst, Oct. 29, 1920, FO 372/1410 [T12369/9008/350].

${ }^{60}$ Minute Tufton, Nov. 8, 1920, FO 371/5479 [W1832/160/98] (emphasis added).

${ }^{61}$ See, e.g., Teixidor, Note pour Dr. van Hamel, Oct. 1, 1920, LNA R1227 [17/7252/7252]; Drummond to Monnet, Oct. 4, 1920, LNA R1227 [17/7252/7252]; Drummond to Balfour; Drummond to Bourgeois; both Aug. 20, 1920, LNA R1219 [17/6077/69].

${ }^{62}$ Teixidor, L'Enregistrement de l'accord franco-belge conclu le mois d'août passé, Sept. 28, 1920, LNA R1227 [17/7252/7252].

${ }^{63}$ Id. On Article 20 of the Covenant, see infra text immediately following note 32.
} 
Eric Drummond, the League's secretary-general, and a former FO official, was skeptical:

If the Franco-Belgian Convention is made up of two separate instruments, the first, what may be called the Diplomatic instrument, and the $2^{\text {nd }}$ solely the technical means by which the $1^{\text {st }}$ will be effected, then of course there could be no objection to No. 1 being registered, while No. 2 was not. . . . If, however, the one Convention includes both the Diplomatic and Military sides, I do not think it possible to register one half of it and omit the other. ${ }^{64}$

While approaches within foreign ministries and the Secretariat up to this point had tried either to exempt certain accords from the class of treaties and engagements to which Article 18 applied, or to withhold "technical" aspects of arrangements, Drummond settled instead on something more radical. Echoing earlier Council discussions, he declared that "if countries choose to take the risk of concluding Conventions which will not be recognised as binding by the other Members of the League, I have always felt they were entitled to do so." 65 Ultimately, the exchange of letters was registered without complaint. ${ }^{66}$

Dionisio Anzilotti (then an under-secretary-general; and from 1921 a judge on the Permanent Court of International Justice (PCIJ)) articulated the same view, but with greater legal sophistication. He conceded that "the background of Article $18 \ldots$ is the principle of open diplomacy" and that "the non validity of unregistered treaties was, in all probability, conceived as a sanction intended to enforce the publication rule . ..." 67 However, he argued that "an objective consideration of the provision in itself, with regard to the circumstances from which it arose and to the place it has in the system of rules of which it forms a part" left open a much more minimalist reading of what it required. He argued:

Before the coming into force of the Covenant, the binding force of international treaties only rested upon the moral force of the promise entered into by the contracting parties. ... The Covenant ... has added to the purely moral sanctions other positive sanctions consisting of the coming into movement of the machinery of the League. It seems therefore quite natural to me that Article 18 of the Covenant be understood in connection with the said sanctions and not otherwise. . . if the parties agree to be obliged by a non-registered treaty, the Covenant has nothing to do with it: the treaty remains beyond the sphere of the League. . . . The Members of the League, therefore, are not unconditionally obliged to register treaties or international engagements entered into by them; they are obliged only if they wish to put the said engagements under the protection of the League. ${ }^{68}$

The early vision of Article 18, reflected in the 1920 Secretariat Memorandum, had understood it as imposing a new condition of publicity on the creation of legal obligation. The Anzilotti/Drummond view reduced Article 18 to a condition merely of access to the particular

\footnotetext{
${ }^{64}$ Memorandum Drummond [to van Hamel], Oct. 1, 1920, LNA R1227 [17/7252/7252].

${ }^{65} \mathrm{Id}$.

${ }^{66}$ Drummond to French MAE, Belgian MAE, Nov. 10, 1920, LNA R1227 [17/7857/7857].

${ }^{67}$ Anzilotti to Drummond, Nov. 11, 1920, LNA R1227 [17/8281/7857].

${ }^{68} \mathrm{Id}$. (emphasis in original).
} 
enforcement mechanisms associated with League membership. ${ }^{69}$ On the latter view, governments retained discretion to move at will between the pre-League order and the League regime. As internal British debates had acknowledged, reading Article 18 in this manner left little role for publicity in ensuring democratic control over foreign policy, or in breaking the cycle of suspicion and belligerence over military arrangements. As Teixidor had noted, it also removed the possibility of ensuring compliance with states' undertaking in Article 20 of the Covenant not to enter into engagements inconsistent with the Covenant (and limited opportunities for the Assembly to advise, under Article 19, on reconsideration of treaties in changing conditions). ${ }^{70}$ Ironically, the Secretariat seems to have embraced a limited reading of Article 18 at least partly because of the pressure of public opinion. The minimalist interpretation avoided both the "patent evasion of the law" inherent in registering only the exchange of letters, but also the appearance of "the weakness and the lack of viability of the League" which would result from a showdown between the Secretariat and the French government. $^{71}$

Nevertheless, these internal Secretariat deliberations did bring to the surface a fundamental difficulty. The view that all treaties should be published, and particularly the Article 18 scheme for registration and publication through the Secretariat, was in some tension with the existing law of treaties. This tension emerged more clearly as the Dutch representative, alarmed at the apparent Franco-Belgian challenge to Article 18, proposed in the Assembly that the Council appoint a committee of jurists to inquire into the provision. The representative, Jonkheer van Karnebeek, outlined three possible interpretations of the status of an unregistered treaty in light of Article 18: ${ }^{72}$

(1) States were genuinely not bound by a treaty pending registration.

(2) States were bound by an unregistered treaty from the moment of ratification, but could not demand execution of the obligations pending registration.

(3) States were bound from the moment of ratification regardless of registration, but precluded from relying on the treaty when appealing to the League unless the treaty had been registered.

None of the three interpretations was entirely convincing. On the first interpretation, a ratified but unregistered treaty had, at best, the status of a pre-Covenant treaty which had been signed but not ratified. This approximated the strong reading of Article 18 reflected in the 1920 Secretariat Memorandum, and shared by most internationalists familiar with

${ }^{69}$ Anzilotti referred to an agreement accepted as binding by the parties, but not registered, as imposing "moral" (perhaps as opposed to "legal") obligations. Id. Drummond thought unregistered treaties were: "Entirely outside the cognizance of the League + therefore impose no moral or material obligation on the other members, nor can any appeal to the League be based upon them . . . binding between the contracting parties only for such time as both feel bound by them." Handwritten comments by Drummond, Nov. 21, 1920, on Anzilotti [to Drummond], Nov. 16, 1920, LNA R1227 [17/8281/7857]. However, the fact that both believed there was no unconditional obligation to register treaties suggests that they still, at some level, understood unregistered texts as treaties.

${ }^{70}$ Drummond had concluded that the Secretariat must "assume that the Convention contains nothing contrary to Article 20, and rely on the pledged word of France and Belgium in this respect." Memorandum Drummond [to van Hamel], Oct. 1, 1920, supra note 64.

${ }^{71}$ Anzilotti to Drummond, Nov. 11, 1920, supra note 67.

${ }^{72}$ Minutes of 7 th Plen. Mtg. (Nov. 19, 1920), in League of Nations. Records of the First Assembly. Plenary Meetings 148, 155-156 (1920) [hereinafter First Assembly: Plenary Meetings]. 
the provision. It was supported by van Karnebeek as conforming most closely to the language of the provision, ${ }^{73}$ and embraced also by Giuseppe Motta (a Swiss delegate), who noted that the popular campaign conducted in Switzerland in favor of joining the League had presented Article 18 as "one of the pillars of the new [League] edifice." 74 However, this first interpretation involved a major shift from the statist, voluntarist creation of legal obligations which had long been central to the law of treaties to a more centralized system in which treaties would have legal force only after the Secretariat's action in registering them.

The second interpretation would mitigate the severity of this shift by preserving the significance of the parties' intention to be bound, and inserting a further stage prior to full entry into force. But this "suspensive" reading, which was perhaps a better fit with the French than the English text, ${ }^{75}$ appeared to emanate from civil law doctrines applicable to private rights. The interim stage, in which parties were bound but could not demand execution, seemed to some commentators a "purely verbal" construction. ${ }^{76}$

The third interpretation was close to the view articulated by Anzilotti and Drummond (although Anzilotti and Drummond were more reluctant to concede the existence of a legal obligation prior to registration). In the Assembly, it attracted support from the politician and former diplomat Tommaso Tittoni, an Italian delegate. ${ }^{77}$ This interpretation was consistent with existing doctrine on the effect of ratification, and minimized the risk of embarrassing confrontations over non-compliance. However, this interpretation focused on the second sentence of Article 18, while virtually ignoring the opening clause ("Every treaty or international engagement ... shall be forthwith registered"). In downplaying the obligation to submit treaties for registration, and leaving governments a choice to make secret treaties provided they did not seek to rely on them before the League, it drained Article 18 of much of its anticipated effect in strengthening democratic control of foreign policy, and in removing suspicions, associated with secrecy, which threatened peace and stability. ${ }^{78}$

From a systemic point of view, perhaps only the first interpretation could have been transformative. The requirement would not have attracted universal compliance—as evidenced by the Franco-Belgian case-but if upheld as a comprehensive norm, it might gradually have caused governments to doubt the reliability of any unpublished treaty, and thus increased incentives to make important undertakings in texts that would be registered and published. However, this kind of systemic argument rarely surfaced in the League debates.

As new scrutiny of Article 18 loomed, the British brought their own challenge into the open. The government wrote to the secretary-general, in correspondence then circulated to all League members, that it had entered into "a large number of financial arrangements, many of them of small general importance ... with a view to completing and liquidating the

${ }^{73} \mathrm{Id}$. at 156.

${ }^{74}$ Id. at 160; see also comments of van Karnebeek in Minutes of 10th Plen. Mtg. (Nov. 23, 1920), in FIRST Assembly: Plenary Meetings, supra note 72, at 203, 209.

75 “Tout traité ou engagement international conclu à l'avenir par un membre de la Société devra être immédiatement enregistré par le secrétariat et publié par lui aussitôt que possible. Aucun de ces traités ou engagements internationaux ne sera obligatoire avant d'avoir été enregistré."

76 See, e.g., Charles Rousseau, 1 Principes généraux du droit international Public 316-17 (1944).

${ }^{77}$ Minutes of 8 th Plen. Mtg. (Nov. 20, 1920) (original erroneously marked Nov. 10), in First Assembly: Plenary MeEtings, supra note 72, at 162, 177.

${ }^{78}$ In which members "solemnly undertake that they will not hereafter enter into any engagements inconsistent with the terms" of the Covenant. 
abnormal transactions rendered inevitable by the war," which the government "[did] not conceive ... were in any way analogous to the Treaties contemplated by Article 18 . ..." The letter announced the government's view that it would be "unnecessary, and in many cases inexpedient" to publish the detail of such transactions. ${ }^{79}$

By late 1920, the British Treasury had clarified that it did not wish to register: (a) agreements with allies for the settlement of claims relating to goods and services supplied during the war; (b) agreements relating to money advances by or to Britain; and (c) agreements for the sale of surplus material. The Treasury believed that texts in categories (a) and (c) were not treaties or international engagements within the meaning of Article 18, but acknowledged that category (b) presented difficulties. These agreements came in a variety of forms. Some might well be treaties or international engagements. However, the Treasury insisted, if these texts were required to be registered and published,

it might well become impossible for any nation to come to the assistance financially of another nation in an emergency ... simultaneous publication [to] the legislative assemblies of the countries concerned . . . might give rise to serious political difficulty . . . [or] entail grave risks to the financial credit of the borrowing country.

Moreover, publication of an agreement postponing payment of debts or reducing rates of interest would no doubt produce analogous requests from other debtors "which it might, on political grounds, be impossible to resist." 80

In a cursory opinion, the British Law Officers (attorney general and solicitor general) advised the Treasury that it could withhold from registration categories (a) and (c), and any agreements in category (b) reached through other than "diplomatic" channels. ${ }^{81}$ The opinion made no attempt to grapple with either the interpretation of "treaty or international engagement" in Article 18, or the definition of a treaty under international law.

In Geneva, van Karnebeek succeeded in his initiative for a committee of jurists to examine "the scope of Article 18 from a legal point of view" and "prepare . . relevant proposals to secure a uniform application of the article in respect of the validity of Treaties." 82 This committee (hereinafter Article 18 Committee) consisted mainly of legal advisers to European foreign ministries, and seemed set to provide the in-depth legal analysis which had not been undertaken on adoption of Article 18. Yet the Committee also struggled to find a principled reading of Article 18 which would accommodate states' desire for a residual possibility of secrecy. The Committee's report was fractured, indicating that the report was a product of compromise, or simply that there were no attractive legal answers. The Committee

\footnotetext{
${ }^{79}$ Spicer to Drummond, Feb. 15, 1921, LNA R1220 [17/11221/69].

${ }^{80}$ Instructions to the Law Officers to Advise [c. Dec. 11, 1920], FO 372/1640 [T1443/211/350]. The sorts of arrangements about which the Treasury were concerned in category (b) included some which were "not even published to our own Parliament." Memorandum B, enclosed in Gower to Hankey, Dec. 11, 1920, FO $372 / 1640$ [T531/211/350] (note that in this earlier memorandum, the enumeration is different, and what would later be category (b) is here labelled category (c)).

${ }^{81}$ Opinion of the Law Officers of the Crown, Jan. 25, 1921, FO 372/1640 [T1443/211/350].

${ }^{82}$ Appointment of the Committee Entrusted with the Examination from a Legal Point of View of the Scope of Article 18 of the Covenant, in 2 League of Nations Official Journal 112 (1921). Of six members nominated by the League Council, five accepted the invitation: Scialoja (former Italian foreign minister and now delegate to the League); Fromageot (legal adviser to the French MAE); Hurst (legal adviser to the FO); Struycken (adviser to the Dutch government); and Maurice Bourquin (legal adviser to the Belgian Ministry of Foreign Affairs).
} 
recognized the aspirations for structural change inherent in Article 18, noting that the "fundamental aim" of the provision was to "suppress secret Treaties, which in the political sphere constitute a danger to the maintenance of peace" and to secure "a broad system of publicity for international engagements." The report offered a relatively strong reading of the existing text of Article 18. It rejected both the Anzilotti/Drummond view that registration was not actually obligatory at all (the third interpretation in the schema above), and the approach taken by van Hamel and Teixidor on the Franco-Belgian military accord, whereby registration of one element of an agreement was considered sufficient compliance with Article 18. It also rejected exceptions like those which France, Belgium, and Britain had purported to find in Article 18, based on the nature, form, importance or duration of international engagements. ${ }^{83}$

Instead the Article 18 Committee devised an interpretation similar to the "suspensive" reading (the second interpretation in the schema above), ${ }^{84}$ but asserted that even this position entailed "impracticable and dangerous" consequences. The report laid out a range of avenues for amending the provision, including: deleting the second sentence of Article 18 altogether; retaining the second sentence but giving registration retroactive effect by changing "unless" to "until"; 85 inserting an "additional article" reflecting the Anzilotti/Drummond approach (the third interpretation in the schema above); ${ }^{86}$ and adding to the obligation to register agreements the words "subject to such provisions as the Assembly may unanimously decide upon," thereby enabling the Assembly to exclude categories of treaties, such as "technical" instruments. ${ }^{87}$

The Article 18 Committee's report triggered, in a series of League committees, the same questions which had dogged the Article 18 Committee's own proceedings. A Sub-Committee of the League's First Committee betrayed some unease about any major qualification to Article 18 as written, and modified the Article 18 Committee's suggested Assembly regulations to require that, even for administrative or technical agreements, the parties submit basic details of the agreement. ${ }^{88}$ In the First Committee, the British fought back, insisting that publication of such details "would in itself be sufficient to produce all the disastrous results which might flow from publication in full." ${ }^{99}$ The lawyer and diplomat Raul Fernandes (Brazil) disagreed; if an agreement opened a credit, there could be no disadvantage in announcing this; indeed "the publicity given to the agreement would constitute an element in the world's tranquillity." 90 Hurst suggested the summary registration procedure would

${ }^{83}$ Report of the Committee Appointed to Study the Scope of Article 18 of the Covenant from a Legal Point of View, Aug. 13, 1921, C.256.M.197.1921.V (A.C.31), at 3 [hereinafter Article 18 Committee Report].

84 "The contract exists from the moment that the consent of the parties has been expressed in the proper forms, and consequently the Powers which have concluded it are no longer free to escape unilaterally from its obligations. But ... the new registration formality ... is a condition which suspends the obligation to fulfil the conventional engagements." Id. at 4 (emphasis in original).

${ }^{85} \mathrm{Id}$. at 5.

${ }^{86}$ Id. at 7 . The proposed insertion read: "No treaty [etc.] . . . may be invoked before the Council or the Assembly, or before the [Permanent Court of International Justice (PCIJ)] or before any other organisation under the authority of the League unless it has been previously registered."

${ }^{87} \mathrm{Id}$. at 6 .

${ }^{88}$ Records of the Second Assembly: Meetings of the Committees, at Annex 11 (1921) [hereinafter SeCond Assembly: Committees].

89 1st Committee, 7th Mtg. [Sept. 26, 1921], in Second Assembly: Committees, supra note 88, at 69-70 (Hurst).

${ }^{90} \mathrm{Id}$. at 70. 
provide an uncontrolled loophole. Fernandes retorted that the effect of Article 18 would not be weakened by summary registration but by failure to register altogether. ${ }^{91}$ Balfour returned to the line of attack he had pursued earlier. He argued that the framers of Article 18 had intended "to put a stop . . . to those arrangements which were fundamentally aggressive in their character," and contrasted treaties of this kind with "the small, transitory, but very necessary, arrangements" which Britain sought to keep secret. He reiterated that "[c]redit was very sensitive, and very easily shattered by public announcements which might be used or misused by interested parties." 92 The British ultimately prevailed, and the First Committee returned to the original recommendations of the Article 18 Committee. $^{93}$

These highly technical debates went largely unnoticed by public campaigners against "secret treaties." In an effort to attract attention, Konni Zilliacus, a committed internationalist in the League's Information Section, passed the Article 18 Committee report, with an explanation of its implications, to the liberal Manchester Guardian. The editor printed parts of the report, suggesting that it undermined the core of Article 18, ${ }^{94}$ and sent the material to the pro-League British politician Robert Cecil, then representing South Africa at the League. ${ }^{95}$ This may have helped mobilize League of Nations Union and Liberal Party support for the preservation of Article 18, and armed Cecil for debate in the plenary Assembly. ${ }^{96}$

In the Assembly, Cecil protested the narrowing of Article 18, and embraced the point made by others, that it was impossible to distinguish between "political" and "technical" treaties. ${ }^{97}$ The Article 18 Committee itself broke ranks, with the Italian legal adviser announcing a personal view that the current language of Article 18 could be interpreted even without express qualification to require only the registration of treaties or even lesser engagements "which may engage the future fate of nations." 98

Debates at the League were frustratingly circular and shallow. No one pointed out that even if the ultimate end of Article 18 had been "put a stop . . to those arrangements which were fundamentally aggressive in their character," 99 this could not be achieved by insisting that states only needed to register these kinds of sensitive treaties. If anything, this would have made compliance with Article 18 even more unlikely. Only a requirement making registration and thence publication an undisputed threshold for any commitments having legal force had any real prospect of incentivizing governments otherwise tempted to secrecy to

${ }^{91}$ Id. at $71 ; 1$ st Committee, 8th Mtg. [Sept. 27, 1921], in SeCOND Assembly: COMmitTeES, supra note 88, at 75.

92 1st Committee, 8th Mtg. [Sept. 27, 1921], in SeCONd Assembly: Committees, supra note 88, at 75-76.

${ }^{93}$ With some minor variations, in SeCOND Assembly: Committees, supra note 88, at 195-201 [hereinafter First Committee Report].

${ }^{94}$ A Threat to the League. The Clause in the Covenant Against Secret Treaties. Hague Committee's Recommendation that it Be Weakened, Manchester Guardian, Sept. 5, 1921, at 9.

${ }^{95}$ Correspondence cited in Ken Millen-Penn, Democratic Control, Public Opinion, and League Diplomacy, 157 World AfF. 207, 211-12 (1995).

${ }^{96}$ See, e.g., Distrust of the Coalition, Times [London], Nov. 25, 1921, at 5; Anson to Secretary-General, Oct. 8, 1921, LNA R1220 [17/16561/69].

${ }^{97}$ Cecil agreed that some means should be devised to exempt minor engagements, which it would be very inconvenient to publish, from the scope of Article 18, but was dissatisfied with the Article 18 Committee's proposals.

${ }^{8} 32$ d Plen. Mtg. [Oct. 5, 1921], in Records of the Second Assembly 851 (1921) [hereinafter Second Assembly: Plenary]

99 1st Committee, 8th Mtg. [Sept. 27, 1921], in SeCond Assembly: Committees, supra note 88, at 75-76. See also, e.g., Seferiades (Greece), id. at 77; Fernandes (Brazil) in 32d Plen. Mtg. [Oct. 5, 1921], in SeCond Assembly: PlenARY, supra note 98, at 850; First Committee Report, supra note 93, at 197. 
make politically significant commitments in texts that would be subject to registration and publication.

Those supporting the Article 18 Committee approach, led by British representatives, ultimately retreated from the attempt to achieve formal amendment of the Covenant, and sought to postpone debate to 1922, subject to an understanding that "in the meantime, Members ... are at liberty to interpret their obligations under Article 18 in conformity with the proposed amendment." 100 The latter part of the resolution was technically not adopted, ${ }^{101}$ but the general tenor of the debates tended to add to accumulated doubts about the scope of Article 18.

As it turned out, further substantive consideration was deferred indefinitely, ${ }^{102}$ and a "silence" fell over Article 18. ${ }^{103}$ The Secretariat declined to take any public position on whether particular texts were required to be registered. It did keep regular lists, sourced from the press, of treaties apparently made but not yet registered, but this information was not used to shame recalcitrant governments. ${ }^{104}$ After a few initial attempts, Drummond largely ceased writing personally to foreign ministry contacts to press for compliance. ${ }^{105}$

Debate in the wider legal community reflected the same divergence of views as existed within League bodies. A report on Article 18 presented to the Institut de Droit International as part of the Institut's ongoing consideration of the Covenant proposed an amendment to Article 18 broadly similar to the one which had finally emerged from the League debates, but which had never been formally approved (i.e., providing that non-registration would merely suspend the parties' obligations, and excepting large classes of instruments from even this narrow provision). ${ }^{106}$ Comments from Institut members ranged from opposition to any compromise of the universal and absolute quality of Article 18, to assertions that, if there was to be a change to Article 18, the provision might just as well dispense with registration for all treaties whose publication appeared inopportune or dangerous to the signatories. ${ }^{107}$ Interwar efforts at codification of the law of treaties were also divided. ${ }^{108}$ Publicists generally reiterated the history of debates within the League organs, and noted that states had fallen short of rigorous compliance. ${ }^{109}$ Perhaps most significantly, the PCIJ

${ }^{100}$ Second Assembly: Plenary, supra note 98, at 851.

101 33d Plen. Mtg. [Oct. 5, 1921], in Second Assembly: Plenary, supra note 98, at 895.

${ }^{102}$ In 1922, Article 18 was back on the agenda of the First Committee, with Hurst, Struycken, and Rolin urging that amendments be adopted, but supporters of Article 18 again managed to postpone consideration of it.

103 Raoul Genet, 3 Traité de diplomatie et de Droit diplomatique 451 (1932).

${ }^{104}$ Hudson to van Hamel, July 9, 1923, LNA R1220 [17/12863/69].

${ }^{105}$ Minute Drummond, Aug. 17, 1922, LNA R1222 [17/22111/69].

${ }^{106}$ Examen de l'organisation et des statuts de la Société des Nations. Rapport de MM. Adatci et Ch. de Visscher, 8 ANNUAIRE DE L'IDI 22, 63 (1923).

${ }^{107}$ Id. at $75,81$.

${ }^{108}$ The Havana Convention on Treaties, Feb. 20, 1928, required publication of treaties after exchange of ratifications but stipulated that a failure to discharge this "international duty" did not affect the force of the treaty, or fulfilment of obligations contained therein: Art. 4. See text reproduced in 29 AJIL Supp. 1205. However, the Harvard Draft convention on the law of treaties assumed that Article 18 was operative, and tried to develop it further. Advisory Committee of the [Harvard] Research in International Law, Codification of International Law Part III: Law of Treaties, 29 AJIL Supp. 657-1226, 912-18 (1935) [hereinafter Harvard Draft].

${ }^{109}$ See, e.g., Walther Schücking \& Hans Wehberg, Die Satzung Des VÖlkerbundes: Kommentiert 655-60 (2d ed. 1924); Manley O. Hudson, Legal Effect of Unregistered Treaties in Practice, Under Article 18 of the Covenant, 28 AJIL 546 (1934); Jean Lambiris, Enregistrement des traités d'après l'article 18 du Pacte de la Société des Nations, in 7 Revue de Droit International \& de Législation Comparée (3D Ser.) 697 (1926); Paul 
(possibly influenced by Anzilotti) seems not to have raised Article 18 in instances in which the PCIJ adjudicated matters related to unregistered treaties. ${ }^{110}$

\section{Assessing the Renegotiation of Article 18}

Debates in the League and the wider legal community left the terms of Article 18 intact, but introduced informal qualifications to its interpretation, and indicated that it would not be strongly enforced. This tacit renegotiation of Article 18 was driven in part by realpolitik concerns: governments' perception of a practical need for secrecy, and the Secretariat's difficulties in enforcing compliance. ${ }^{111}$ However, one can also see in the various League bodies doubts at the level of principle, particularly concerning financial relations: was secrecy always inimical to peaceful relations, or was it, in fact, necessary to maintain them?

These early responses to Article 18 challenged the intuition that publicity and legal force went hand in hand. Much depended on the vision of law at stake. The 1920 Secretariat Memorandum had sought to entrench publicity as a condition of legal force, and this approach, which would have cast doubt on the reliability of secret undertakings, was probably the only path by which Article 18 could have changed behavior. However, this approach was premised on a major shift in international law, in which the League Secretariat held at least a formal role in bringing treaties into operation. This was difficult to reconcile with then-dominant understandings of international law, in which states decided both what treaty obligations to accept, and whether or not they needed to be published. As one jurist put it, Article 18 was "a case in which the generous impulse towards a more perfect international organization runs up against obstacles deriving from a deep-rooted status quo, and in which the principle stated does not correspond to the collective legal consciousness." 112

Early struggles over the interpretation of Article 18 showed the law itself to be a complex instrument, rather than a neutral means of transforming the interstate order. Not only did the deep structure of the law of treaties weigh against making registration and publication a condition of binding force; but, as the Franco-Belgian accord showed, the complex vocabulary of treaties, together with crafts of drafting, created avenues for secrecy. Moreover, the transposition of political condemnation of "secret treaties" into the realm of legal obligation arguably blunted the impetus for change. What had appeared a clear objective-all treaties must be

Fauchille, 1(3) Traité de droit international public 335-45 (1926); Charles Cheney Hyde, 2 International Law Chiefly as Interpreted and Applied by the United States 6-7 (2d ed. 1922); C. Sevens, Le Régime nouveau des traités internationaux (1925); Jean Ray, Commentaire du Pacte de la Société des Nations SElon la politique et la juRisprudence Des organes de la Société 545-58 (1930); Dionisio Anzilotti, Cours de Droit international 374-92 (Gilbert Gidel trans., from 3d Italian ed. 1929); L. Oppenheim, 1 International Law: A Treatise 730-32 (A. D. McNair ed., 4th ed. 1928); Georges Scelle, 2 Précis de droit international: Principes et systématique 484-88 (1934); Ladislas Reitzer, L'Enregistrement des traités internationaux, in REVUE GÉNÉRALE DE DROIT INTERNATIONAL PUBLIC 67 (1937); EDOARDo VitTA, LA VAlidité des traités INTERNATIONAUx 238-47 (1940).

110 There were at least two cases in which the PCIJ adjudicated matters arising under an unregistered treaty, although in both cases, at least one party to the unregistered treaty was a non-member, and the instruments were well-known to the League, which might have made non-registration politically, if not legally, trivial. In further cases, the special agreement conferring jurisdiction was itself not registered. For details see Hudson, Legal Effect, supra note 109 , at 552 .

${ }^{111}$ Resource constraints may have dissuaded the Secretariat from trying to increase submission rates over time: even after a block subscription/subsidy organized by Manley Hudson and channelled through ASIL in 1923-24, there were ongoing struggles finding funds for proofreading and printing the Treaty Series.

${ }^{112}$ VITTA, supra note 109, at 247. 
public - became entangled in debates that were so complex and technical as to dissuade public engagement.

\section{Interwar Experiments: Entrenchment of Publicity, Refinement of SeCrecy}

\section{Domestic Law and Bureaucratic Practice}

Once the force of Article 18 had been called into question, domestic law constituted the major constraint on treaty practice. ${ }^{113}$ In France and the United States, there were no major changes to the constitutional position of the pre-war years. In Britain, on the other hand, the first Labour government sought in 1924 to introduce a constitutional requirement for parliamentary approval, or at least opportunity for discussion, of all treaties prior to ratification. ${ }^{114}$ Cecil Hurst, the FO legal adviser, discouraged any move toward requiring parliamentary approval, and suggested that publicity, and thus some measure of democratic control, could be accomplished by simply laying treaties once signed, instead of after ratification. ${ }^{115}$ The new policy was signaled by a statement by the foreign secretary in the House of Commons, that "every Treaty" would be laid, when signed, for twenty-one sitting days, before ratification. ${ }^{116}$ After a brief suspension when the Conservatives returned to power (1924-29), this "Ponsonby rule" was gradually entrenched as a convention. ${ }^{17}$ However, the focus on treaties requiring ratification may have obscured the non-publication of treaties not subject to ratification. Hurst had believed that such "international agreements, usually of a technical or administrative character ... do not as a rule raise political issues, nor do the public at large or the Legislature desire to be bothered with them," 118 but it was not always the case that such treaties were devoid of political significance.

In all three states, approaches to registration appear to have been shaped not only by domestic law, but by bureaucratic structures and processes. As the United States was never a member of the League, U.S. publication practice was relatively unaffected by Article 18. At least some "executive agreements" were considered treaties capable of binding the state under international law, ${ }^{119}$ and a new Executive Agreements Series was launched alongside the Treaty Series in 1929, but some executive agreements were not published. ${ }^{120}$ Manley Hudson, who worked in the League's Legal Section during U.S. summers even after leaving

\footnotetext{
113 There was still some disagreement about whether a failure to satisfy the demands of domestic law affected the validity of a treaty under international law. See Harvard Draft, supra note 108, at 996-1008.

${ }^{114}$ Ponsonby to Hurst, Feb. 1, 1924, FO 372/2114 [T1291/1291/381].

${ }^{115}$ Hurst, Submission of Treaties to Parliament before Ratification, Feb. 5, 1924, FO 372/2114 [T1291/1291/ 381] [hereinafter Hurst, Submission of Treaties].

${ }^{116}$ HC DeB., supra note 45, at vol. 171, col. 2003 (Ponsonby, Apr. 1, 1924). Ponsonby's statement had referred to the need to capture "agreements, commitments, and understandings by which the nation may be bound . . . although no signed and sealed document may exist," but this aspiration was largely forgotten in the years to come.

117 Subject to a capacity to set it aside at Cabinet discretion in urgent cases (Parliament to be informed thereafter). For subsequent refinements of Parliamentary procedure, see Evans and Anderson, The Presentation of Treaties to Parliament: The Ponsonby Rule, Mar. 31, 1969, paras. 17-24, FCO 53/81 ["FCO” in archival references denotes National Archives (UK), Foreign \& Commonwealth Office papers (held at Kew)].

${ }^{118}$ Hurst did, however, comment on the difficulty of making ex ante distinctions between important and unimportant treaties. Hurst, Submission of Treaties, supra note 115.

119 See, e.g., discussion in Harvard Draft, supra note 108, at 696-98.

120 Wallace McClure, International Executive Agreements: Democratic Procedure Under the Constitution of the United States, at xii-xiii (1941).
} 
full-time service in 1921, brokered an arrangement in 1925 whereby the United States would send treaties appearing in the Treaty Series to the League Secretariat, to be "entered" (but not registered). When another signatory was a League member, the Secretariat would seek submission from them of the text for actual registration, and only later, if no submission was forthcoming from the member, print the text provided by the United States in the League of Nations Treaty Series (LNTS), under a system of numbering distinct from that used in the main series. ${ }^{121}$ This procedure delayed the publication in the LNTS of U.S. treaties. From 1934, again following Hudson's activism, ${ }^{122}$ the United States agreed to submit treaties for registration like any League member, but on the condition that the United States was not thereby acquiescing in the stipulation of Article 18 that no instrument be binding until registration. ${ }^{123}$ Although the 1934 arrangements were not explicitly limited to treaties already published in the Treaty Series or Executive Agreements Series, there is no indication that officials contemplated sending to the Secretariat any texts which they would not otherwise have published.

Within the British Foreign Office, the Treaty Department was responsible for both the integrity of internal records and the transmission of texts as appropriate to Parliament and the League. These tasks were mutually reinforcing, and officials had a certain pride in the accuracy of their work, making them (usually) voices in favor of registration. In the French MAE, on the other hand, there was no ongoing treaty series akin to those in the United States and United Kingdom (treaties requiring promulgation simply appeared in the general Journal Officiel), and this may have been both a symptom and a cause of relatively limited attention to publication. Moreover, the task of registration was given initially to a new League liaison service within the ministry, rather than the services usually responsible for the custody of treaties (Protocol and Archives), and this dispersal of roles may have contributed to the marginalization of registration. In 1928, it was conceded that "until now, and it is a matter which $\mathrm{Mr}$ Fromageot [the legal adviser] has raised several times, we have often neglected to complete this formality of registration." ${ }^{124}$ It was only in 1928 that it was laid down that, once the decree of promulgation had been published in the Journal Officiel, the treaty would be sent for registration. Texts not published in the Journal Officiel, of which there were apparently a considerable quantity (see further below), were not to be sent for registration, other than on specific instructions. ${ }^{125}$

\section{Techniques of Secrecy}

The interwar period saw common techniques in Britain and France for the preservation of secrecy where this was considered desirable, including recourse to texts of ambiguous status, and packages of layered texts. However, there were differences in national styles. The French MAE was more inclined to rely on a general exception for "technical" texts, which was highly

\footnotetext{
${ }^{121}$ Manley O. Hudson, Registration of United States Treaties at Geneva, 28 AJIL 342, 344 (1934).

122 On Hudson's personal involvement, see Hudson to Avenol, Feb. 1, 1934, LNA R3826 [3D/9266/2084].

${ }^{123}$ Correspondence excerpted in Hudson, Registration of United States Treaties at Geneva, supra note 121, at

${ }^{124}$ Note pour Monsieur Berthelot, [Enregi]strement des traités, May 1, 1928, with handwritten annotations by Fromageot, MAE SDN 20 [IA.4/3].

${ }^{125} \mathrm{Id}$.
} 344-45. 
flexible, albeit legally plausible insofar as it reflected gradations of importance and detail that had long lain beneath the positivist notion of treaty.

In Britain, the Law Officers' 1921 opinion, mentioned above, articulated exceptions to Article 18 on which the Treasury and Board of Trade leaned heavily. ${ }^{126}$ Many agreements settling claims, or for the sale of surplus material, were not registered or published in the Treaty Series, although these may have been regarded as outside the scope of treaties in any event. A large number of borderline texts concerning administration of reparations, not actually referred to in the opinion, were treated as analogous. ${ }^{127}$

The FO tolerated secrecy in other circumstances, accommodating it through texts of indeterminate status, or the old drafting technique of splitting commitments between a (published) principal text and a (secret) ancillary text. The former approach is exemplified by a 1927 "Record of Conversations" between the British ambassador in Rome; the governor of the Italian colony of Eritrea; and the director-general of the Italian Ministry for Foreign Affairs. ${ }^{128}$ This rather convoluted text, referred to later as the "Rome Understanding," stated that the delegates:

acting under their instructions that the respective policies of the two Governments in Southern Arabia and the Red Sea should be pursued in a spirit of friendly co-operation and developed on parallel though independent lines, have reached the conclusion that their Governments are in agreement on the following points . . . 129

One clause recorded that "His Britannic Majesty's Government regard it as a vital imperial interest that no European Power should establish itself on the Arabian shore of the Red Sea" and that Italy, in view of possessions on the west coast of the Red Sea, had an equivalent interest. ${ }^{130}$

When the signed texts arrived in the FO, the initial instinct was to submit them for registration, but some doubted whether they constituted an "international engagement." 131 The secretary of state preferred not to submit them, on the basis that this "might create an

\footnotetext{
126 See supra text at note 81 . Beckett, then second legal adviser, thought the Law Officers' opinion "not altogether convincing." Minute Beckett, Jan. 19, 1933, FO 371/15927 [C5374/455/62]. He clarified: “The real test is the nature [rather than the form, or manner of conclusion] of the agreement. . . If the agreement is one which is intended to create binding legal obligations under international law, it should be registered." Minute Beckett, Mar. 9, 1933, FO 371/16630 [C77/77/3].

127 See, e.g., an Anglo-Uruguayan agreement of 1927, expressed as being between the two governments, providing for the handing over to the Reparations Commission of certain German-flagged ships requisitioned by the government of Uruguay during the war and the handling of expenses related thereto. The Treasury resisted registration on the basis that " $[\mathrm{t}]$ he Agreement is not of course a Treaty, but an executive arrangement for dealing with reparation deliveries, such as is made by various Powers every few months.” Waley to Troutbeck, Jan. 14, 1927, FO 371/12128 [C 416/119/18]. In the FO, an official noted: "It is awkward, but there must be a considerable number of such agreements that we have not registered, and in some cases have not seen. . . . It is difficult to draw any artificial distinction between what we ought to register ... and what we need not ...." Minute Ritchie, Jan. 21, 1927, FO 371/12128 [C 416/119/18]. The agreement was not submitted for registration by Uruguay either.

${ }^{128}$ Enclosure in Graham to Chamberlain, Mar. 11, 1927, FO 371/12236 [E1369/22/91].

${ }^{129} \mathrm{Id}$.

${ }^{130}$ Id., para. 4.

${ }^{131}$ Ritchie thought it was not; another official retorted: "It has the appearance of being an international engagement." Osborne and Oliphant characterized it as a "gentlemen's agreement," meaning, in this context, not legally binding. Minutes Mar. 30, 31, and Apr. 1, 4, 1927, FO 371/12236 [E1369/22/91].
} 
undesirable precedent." 132 This decision was received in the Treaty Department as a legitimate reading of ambiguous texts in circumstances where the line between treaty and "gentleman's agreement" was hard to draw. Yet when the FO looked again at the texts a decade later, as an expansionist Italian policy in the Yemen seemed more threatening, the earlier judgments seemed questionable. It was feared that any public assertion of British interests would ultimately lead to discovery by members of Parliament (MPs) of something which they "might regard as a secret agreement." 133 On one hand, it was argued internally that

there is nothing "secret" about the Understanding in this sense. It was a purely informal agreement, in the nature of diplomatic discussions and correspondence, and the time there seemed no more reason to publish it than to publish any other part of the correspondence passing between His Majesty's Embassy and the Italian Government. ${ }^{134}$

But this was not quite true. From the outset the texts had struck some officials as having the quality of an "international engagement." The formality of two languages, the finality of the statement of a mutually shared position, and the significance of the content had seemed to indicate a legally binding commitment. On the other hand, the carefully chosen wording ("parallel though independent policies") and the "conclusion that [the] Governments are in agreement" tended to suggest a mere statement of fact about the governments' beliefs. Regardless of whether the failure to submit the texts for registration had been technically defensible, officials knew that fine distinctions between engagements and gentlemen's agreements would not be intelligible or convincing to Parliament. ${ }^{135}$

An alternative technique for accommodating secrecy involved splitting obligations across a (published) principal and (secret) ancillary text. Where issues were important, and the government feared that the other party might renege on anything agreed in secret, officials insisted on publication of ancillary texts, reasserting a relationship between publicity and legal force. ${ }^{136}$ On other occasions, the United Kingdom did accept secret ancillary texts, the terms of which had some claim to binding force through their relation to the principal text.

Secret ancillary texts were particularly prevalent in relations with polities which, while nominally independent, were within a British sphere of influence. While the Anglo-Iraqi

${ }_{132}$ Minute [illegible], Apr. 8, 1927, FO 371/12236 [E1369/22/91].

133 Draft Memorandum for the Middle East (Ministerial) Sub-Committee of the Committee of Imperial Defence, Future Policy in regard to the Yemen [c. July 1937], FO 371/20781 [E3941/872/91].

${ }^{134} I d$.

${ }^{135}$ Eden eventually stated the British aspect of the Understanding in the Commons: "It has always been, and it is to-day, a major British interest that no great Power [including Britain] should establish itself on the Eastern shore of the Red Sea." HC Deв, supra note 45, at vol. 326, col. 1805 (July 19, 1937). The existence of written terms was kept secret even after this point, and inquiries discouraged. See minutes [illegible], Oct. 6, 1927, and Oct. 12, 1927, FO 371/20781 [E5795/872/91].

${ }^{136}$ See, e.g., insistence on publication of Anglo-Persian notes concerning jurisdictional arrangements for a naval facility on Henjam island. This would involve "loss of face" to the Persian Government (Clive [Tehran] to FO, Sept. 3, 1930, FO 371/14528 [E4773/20/34]). However, it was considered vital that these notes be published in order to avoid difficulties with local officials. Flint (Admiralty) to Under Secretary of State, FO, Sept. 12, 1930, FO 371/14528 [E4932/20/34]. Some officials rejected the absolute position that unregistered notes could not be invoked as a legal engagement, but the primary concern in doing so was to avoid making statements which might encourage the Persian Government to flout undertakings made in regular diplomatic correspondence. Minute Rendel, Sept. 11, 1930, FO 371/14528 [E4773/20/34]. 
Treaty of Alliance of 1930, for example, was registered and published, it was nestled among exchanges of notes and side letters "interpreting" the treaty, only some of which were published. ${ }^{137}$ The Anglo-Iraqi Treaty was a prelude to transition from British mandate to a new form of internationally brokered "independence" as informal empire, ${ }^{138}$ and the notes and letters were often crafted to preserve an appearance of independence and symbolic prestige.

One note concerned a special guard, consisting of Iraqi troops under British officers, for the protection of British air bases in Iraq (British air force presence having been a major source of tension in negotiations). ${ }^{139}$ It was understood that the note would not be registered or published, but the Embassy in Baghdad contended that

[i]t was ... made perfectly clear at the time that Nuri's note, or secret letter as it is generally called, would be binding on the Iraqi Government as faithfully describing "such conditions as may be agreed to between the High Contracting Parties" [referred to in para. 4] of the Annexure to the Treaty of $1930 .{ }^{140}$

The secret text was thus not legally binding in its own right, but provided further details of a binding and public obligation into which it was arguably merged.

Four years after the signature of the Anglo-Iraqi alliance, a new Iraqi government sought to publish some of the 1930 correspondence. As with the Anglo-Italian "record of conversations" discussed above, looking with fresh eyes at the correspondence prompted questions. An official observed that "the dividing line between some of these notes . . . and an 'international engagement' which should be registered . . . is rather thin." ${ }^{141}$ Fitzmaurice, the assistant legal adviser, noted that "it would obviously be misleading" to submit the treaty for registration without accompanying notes if the notes "place a special meaning on [a] clause ... different from that which an ordinary reader might assume from the terms of the treaty itself." 142 It was decided, however, that it was better not to register late, and to simply "brazen out" the earlier failure to register if it came to light. ${ }^{143}$

The use of ancillary texts as an avenue for secrecy was also rife in the trade context, particularly as protectionist measures in the 1930s exacerbated struggles for commercial advantage. The FO thought "the growing [Board of Trade] habit of having their agreements in two parts, the innocent one for publication and the less innocent to be kept secret" was "reminiscent of the secret treaties which we have been trying to get away from since the war," ${ }^{144}$ and objected

\footnotetext{
137 Treaty of Alliance Between His Majesty in Respect of the United Kingdom and His Majesty the King of Iraq, with an Exchange of Notes ... Together with Notes Exchanged Embodying a Separate Financial Agreement, UK Treaty Series No. 15 (1931), Cmd. 3797.

138 Susan Pedersen, The Guardians: The League of Nations and the Crisis of Empire 262-86 (2015).

139 Said to Humphrys, June 30, 1930, FO 371/14508 [E4557/41/93].

${ }^{140}$ Chancery, British Embassy Baghdad, to FO Eastern Department, Dec. 13, 1934, FO 371/17858 [E7692/ 190/93].

${ }^{141}$ Minute Nicoll, June 5, 1934, FO 371/17858 [E3214/190/93]. See also minute [illegible], June 13, 1934, FO 371/17858 [E3214/190/93] ("I confess to feeling some doubt about the propriety of not publishing these notes. They may not be of first class importance + some of them may merely extend a previous arrangement but they appear to constitute international obligations.").

${ }^{142}$ Minute Fitzmaurice, Sept. 4, 1934, FO 371/17858 [E3214/190/93].

${ }^{143} \mathrm{Id}$.

${ }^{144}$ Minute Troutbeck, Oct. 19, 1936, FO 371/19760 [A8272/59/2].
} 
to the French practice of withholding agreements "by just labelling them 'administrative agreements."' 145 However, the Board of Trade argued that secrecy

has become so widespread in other countries that we have found it impossible to avoid the infection ... most of our trade agreements contain confidential letters ... perhaps the chef d'oeuvre is the Polish Agreement which contains more confidential than public matter! ${ }^{146}$

The Board of Trade in turn felt inhibited from complaint about other countries' practices because "their own consciences are not entirely clear."147

In Britain, then, possibilities for secrecy subsisted, but secrecy tended to be accommodated only for matters of apparently secondary importance (however politically salient in reality). It was only as the international situation darkened in the late 1930s - a time when fascist powers were entering into secret treaties foreshadowing war ${ }^{148}$ — that Britain resorted to secret commitments in the realm of high politics. ${ }^{149}$

The French MAE undoubtedly left unpublished and unregistered many of the sorts of reparations, trade and financial agreements which also escaped publication in the United Kingdom, ${ }^{150}$ but went further, keeping secret a series of "military accords" made between France, on one hand, and the "Little Entente" (Czechoslovakia, Romania, and Yugoslavia), on the other. These military arrangements, aimed at reinforcing the continental status quo and fostering military collaboration, were more obviously politically salient.

Drafting followed loosely the precedent of the Franco-Belgian military accord, with one or more public texts (often termed "political"), and military stipulations in an ancillary text (sometimes described as "technical") not intended for publication or registration. In 1921, for example, France and Poland entered into a "political accord" and a "military accord." The political accord was signed by the respective foreign ministers; the military accord by ministers of war; and an annex to the military accord by generals and (in the French case) the minister of finance. ${ }^{151}$ The political accord contained very general provisions committing France and Poland to cooperation in matters of foreign policy and economic recovery, and providing that if one party suffered an unprovoked attack, the two governments would cooperate for the defense of their territory and legitimate interests. The military accord, styled as being "in execution of" the political accord, contained more concrete commitments to cooperate

${ }^{145}$ Minute [Collier], Oct. 31, 1934, FO 371/18294 [N5961/1148/30].

${ }^{146}$ Brown [Board of Trade] to Cadogan, Oct. 28, 1936, FO 371/19760 [A8582/59/2].

${ }^{147}$ Minute [Grey?], Oct. 30, 1934, FO 371/18294 [N5961/1148/30].

${ }^{148}$ Most notoriously, the Molotov-Ribbentrop "Treaty of Non-Aggression” of Aug. 23, 1939, accompanied by a secret additional protocol defining respective "spheres of influence" that carved through Polish territory and the Baltic states. Nazi-Soviet Relations, 1939-1941: Documents from the Archives of the German Foreign OfFICE 76-78 (Raymond Sontag \& James Beddie eds., 1948).

${ }^{149}$ The published Anglo-Polish Agreement for Mutual Assistance of August 1939, for example, provided that each party would at once give all the assistance in its power to the other party should it be subject to aggression or threats to independence by a "European power." A secret protocol, said to constitute an integral part of the Agreement, specified that "European power" meant Germany. It was publicly acknowledged in 1939 that German aggression was the main source of concern (HC DEB, supra note 45, at vol. 352, col. 1082 (Butler, Oct. 19, 1939)), but the protocol was not published until 1945: Cmd. 6616 (1945).

${ }^{150}$ See, e.g., correspondence about various agreements in MAE 118 CPC 216 [Z760/5-6] (Yugoslavia); MAE 110 CPC 225-6 [Z586/5-6] (Romania).

${ }^{151}$ See 1 Documents Diplomatiques Françals 1921, at 215-19, 235-36 (2004). 
should Germany or Russia take particular steps, and provisions requiring Poland to develop its national forces, including by instituting two-year compulsory military service, and maintaining a peacetime strength of a certain number of divisions. ${ }^{152}$ France undertook to contribute military credits to the sum specified in the annex. The general staffs undertook to keep each other informed of preparations and measures necessary to the execution of the accord and the maintenance of lines of communication between the countries.

The political accord was to be published almost in its entirety. ${ }^{153}$ The military accord and its annex were not to be published at all. ${ }^{154}$ Despite the variation in signatories, it seems to have been assumed that the texts all bound the French state as such (rather than ministers or generals personally). Internally, the French analogized this case to the Franco-Belgian episode, in which registration of only the covering letters had been accepted. ${ }^{155}$ The League Secretariat registered the political and commercial accords without posing any questions. ${ }^{156}$ A similar pattern, albeit with less firm and detailed military components, was followed for arrangements between France and other members of the Little Entente. ${ }^{157}$

Internal French documents suggest that diplomats and MAE officials understood the secret military accords and other ancillary texts to have legal force, as far as they went. It was occasionally noted that the Franco-Polish annex on military credits was an agreement of a kind which, under the constitution, was not valid unless approved by the legislature, ${ }^{158}$ but there was no attempt to grapple with this fact. Admittedly, officials conceived of obligations in a holistic way, and rarely tried to disentangle those having force on legal grounds from those whose force was derived from, for example, a moral requirement to adhere to undertakings once made, or considerations of national self-interest. There was not scrupulous compliance with all terms of the secret texts, any more than the public ones. Nevertheless, officials invoked secret texts as a source of obligations in internal correspondence, and discussions with foreign counterparts. ${ }^{159}$ Internal lists of France's treaties, alliances, and

${ }^{152}$ It was later acknowledged that the structure of the Franco-Polish accord was artificial: "[A]lthough it was signed only by military delegates of the two countries, [the military accord] was not only a [c] onvention of military execution [convention d'exécution militaire]; it comprised a series of articles of a genuinely political character as they determined the cases in which the cooperation of the two countries must be effected." Note pour le Président du Conseil, Jan. 29, 1922, MAE CPC 132 [Z698/12\&13].

${ }^{153}$ Minus an article providing that it would only come into force on the execution of commercial accords then under negotiation. This article was withheld out of fear that Polish critics of the arrangements might read the article in question as confirmation that France's pursuit of economic interests had dominated the whole relationship. Panafieu to MAE, Mar. 5, 1921, MAE CPC 132 [Z698/12\&13].

${ }^{154}$ Note pour le Président du Conseil, supra note 152.

155 Note, Feb. 14, 1923, MAE CPC 133 [Z698/12\&13, no. 133].

156 See 2 LNTS 128.

157 Details in Donaldson, supra note 23, 369-73.

158 See, e.g., Note pour le Président du Conseil, supra note 152.

${ }^{159}$ E.g., the French speak of the need for clauses of the Franco-Polish military accord to be executed "strictly and without delay," and the Poles, upset about French delays in granting military credits, insist that the engagement to supply the credits had been entered into by the French without qualification or reserve and must be kept. Président du Conseil to Foch, Aug. 31, 1921, MAE CPC 132 [Z 698/12\&13]; Note pour le Président du Conseil, supra note 152. See also Foch to Président du Conseil, July 1, 1921; Président du Conseil to Foch, Aug. 31, 1921; Ministre plénipotentiaire of Poland in Paris to the Ministre des Affaires Étrangères (France), Mar. 24, 1922 (original erroneously marked 1921); Président du Conseil to Ministres de la Guerre and others, Mar. 31, 1922; Note, Négociations Franco-Polonaises, Application de la Convention Militaire, Apr. 26, 1922; all MAE CPC 132 [Z 698/12\&13] (concerning Poland's obligations to reorganize its army and extend military service, and France's obligations to extend the credits); Note sur les échanges de vues et les accords de la Pologne avec les états de la 
"contractual obligations" referred to both public and secret texts, mentioning which had been published and which had been secret but not otherwise suggesting that the secret texts lacked legal force. ${ }^{160}$ In a draft speech for the French foreign minister, which originally claimed that French relations with friendly countries of East and Southeastern Europe "remain founded on public accords which do not threaten anyone and in no way limit the development of peaceful relations between their signatories and the other States of Europe," the word "public" was carefully struck out by hand. ${ }^{161}$ Other countries, including Britain, knew or suspected that the secret texts existed, and incorporated them into assessments of relations between the various countries. ${ }^{162}$ This might merely reflect the insignificance of distinctions between legal and extra-legal obligation, particularly in the military context, but it also suggests that no sharp distinction was made between the legal force of public and secret texts.

Despite the elaborate drafting, the existence of military commitments did not actually remain secret in any of these cases. The undertakings made in the Franco-Polish military accord required domestic legislative action in both states (in Poland, the institution of two years' compulsory service, and in France, the grant of military credits) that was difficult to reconcile with secrecy. ${ }^{163}$ The French Senate Finance Committee demanded a copy of what it believed was a "financial convention" underpinning the military credits, but was actually the military accord and its annex. ${ }^{164}$ The Polish minister in London observed that "this accord had been drafted most clumsily," and proposed replacing it with a text which would mention a loan without specifying the military aspect. ${ }^{165}$ Further deliberation was short-circuited when the Frankfurt Gazette published a summary of the (public) political and (secret) military accord. The conclusion of clusters of public and secret instruments with Czechoslovakia and Romania were also followed by press rumors or disclosures. In responding to press and public criticism, statesmen and officials could exploit the ambiguous status of ancillary, secret texts, and shift between a broad lay notion of "treaty" and narrower senses common in diplomatic discourse, but not widely shared by the public. ${ }^{166}$

Petite Entente de l'Entente baltique, May 28, 1923 (concerning Poland's obligations to inform France of treaties negotiated with other states); Warsaw to MAE, Aug. 14, 1924 (concerning France's obligations to concert with Poland); both MAE CPC 134 [Z 698/12\&13].

160 See, e.g., État des traités et des accords d'alliance, May 1, 1928; Notes sur les accords politiques franco-polonais, Nov. 24, 1937; Obligations contractuelles de la France et de la Tchécoslovaquie, Nov. 27, 1937; MAE CPC $479[\mathrm{Y} 61 / 4]$.

${ }^{161}$ Projet de texte pour le discours du Ministre, Jan. 18, 1939, MAE CPC 479 [Y61/4].

162 See, e.g., Memorandum: Political Treaties, Agreements, Alliances and Relations at present in force in Central and South-East Europe affecting the Question of Security, Jan. 20, 1925, FO 371/10698 [C982/982/62].

${ }^{163}$ Note pour le Président du Conseil, supra note 152.

${ }^{164}$ Note pour le Président du Conseil, June 24, 1922, MAE CPC 133 [Z698/12\&13].

${ }^{165}$ Visite du Ministre de Pologne à M. de Peretti, Feb. 1, 1922, MAE CPC 132 [Z698/12\&13].

${ }^{166}$ E.g., publication in a German newspaper of what purported to be the text of a secret Franco-Czech military treaty, but was actually a fake, turned out to be a gift for the French and the Czech governments. They could happily issue démentis, and Benes declared before the Czech Foreign Affairs Committee that he had not, and would not in the future, sign any "secret treaties." See Ministre de France, Prague, to Président du Conseil, Mar. 22, 1924, MAE CPC 42 [Z864/12]. The démenti was amplified in the Francophone press. See extracts in dispatches in MAE CPC 42 [Z864/12]. 


\section{The Interwar Legacy}

Article 18, as the first norm of treaty publication in international law, did have considerable effects. Most League members submitted at least some of their international engagements for registration, ${ }^{167}$ and the rhetorical embrace of publicity inherent in Article 18 gave domestic legislatures and publics a new benchmark against which to criticize secrecy. Nevertheless, Article 18 was not able to achieve the definitive split it promised on its face, between a universe of legally binding obligations, all of which would be registered and published; and a hinterland of secret obligations which, whatever their hold in interest or honor, had no legal significance.

Experience in the 1920s and 1930s suggested, even to proponents of publicity, that the connections between publicity and the ideals it had been intended to serve were more attenuated than anticipated. While perhaps necessary for democratic control of foreign policy, the norm of treaty publication was far from sufficient to secure this end. As even Ponsonby came to acknowledge, opportunities for debate in Parliament were rarely taken up. ${ }^{168}$ The relation between publicity and peace had already been questioned in the 1920s, when secrecy about some interstate financial dealings seemed conducive rather than damaging to peace, and in the 1930 s, secrecy of military accords came to seem, at least to the "status quo" powers who had emerged victorious from WWI, essential for defense and the stability of the international order.

The relationship between the norm of publication and the fostering of legality in interstate relations was also highly complex. The basic intuition that legal obligations were, or should be, public had gone hand-in-hand with a new, institutionalized vision of international law. This had been countered by a voluntarist tradition in which states remained the ultimate arbiters of their obligations to each other, and the extent to which these obligations would be rendered public.

The vision that the norm of treaty publication would change the conditions of interstate interaction, and help to construct a more law-governed international order, also came under pressure. The norm probably did contribute to the wider dissemination, and possibly thus the systematization and coherence, of international law, by establishing the League of Nations Treaty Series as a unitary repository of authenticated and translated texts. But whether it entrenched a deeper orientation to legality in governments was difficult to say. The fact that some secret treaties made arrangements for conduct in violation of international law tends to reinforce the notion that secrecy and power politics went together, in opposition to publicity and respect for law. On the other hand, many secret treaties did not contemplate

\footnotetext{
${ }^{167}$ In the first full year of the League's operation (1921), 128 treaties were submitted for registration. The figure grew rapidly in the mid-1920s to 350 (1926), before tapering in the late 1920s. These figures are from Manley O. Hudson, The Registration of Treaties, 24 AJIL 752, 753 (1930). This certainly does not represent the totality of treaties made by League members, or even published in national collections. Raw figures on the number of treaties submitted are a very inadequate proxy for national compliance, but in the period 1920-1930 the British Empire submitted the most treaties, followed by Germany, then Scandinavian and some European countries (the United States was not submitting treaties for registration at this stage: see above text at note 121). France submitted considerably fewer treaties than the United Kingdom. There were relatively strong submission figures from some of the new states of eastern Europe, perhaps reflecting the close engagement of some of these states and their leaders with the League, but comparatively few submissions from Latin America; thirteen submissions each from China and Siam; and four from Persia. Id. at 754-55.

${ }^{168}$ House of Lords Debates, 5Th Ser., vol. 86, cols. 793-94 (Feb. 22, 1933) [hereinafter HL Deb].
} 
action in violation of law. Indeed, precisely because they were secret, and signatories lacked an institutional and rhetorical apparatus for their enforcement, some secret treaties might actually be seen as a mark of faith in the power of legal obligation alone to guide states' conduct.

There are indications that the norm of publication empowered a broader range of states as legal actors, vindicating formal sovereign equality over informal hierarchy. One striking illustration is furnished by dealings in the 1920s between Britain, France, and Italy regarding respective rights in Ethiopia. Frustration on the British side with Ethiopian reluctance to accept a dam project essential for development in the Sudan drove Britain to enter into a 1926 exchange of notes with Italy, whereby each would support the other in seeking desired concessions from the Ethiopian government. The regent of Ethiopia, Ras Tafari, heard of the agreement, and protested that he "[did] not understand why the two Governments [had] contracted together to consider action inside the jurisdiction of Ethiopia before we heard anything about it."169 The FO and Italian counterparts toyed with various possibilities, including splitting the agreement into secret and public parts, ${ }^{170}$ but the necessity of registration and publication, in light of Ethiopia and parliamentary interest in the agreement, made it clear that dissembling over the text itself would be unwise. ${ }^{171}$ The parties settled for only minor alterations before showing the text to Ras Tafari. ${ }^{172}$

In reinforcing national publication practices, Article 18, together with the existence of the League as a platform, made a tangible difference to Ras Tafari's possibilities of resistance. British MPs asked probing questions about the intent behind the exchange and, while their criticisms were often stymied, as the government repeatedly rejected interpretations of the letters by MPs and the press, they drove Chamberlain to issue an explicit denial of any coercive intent. ${ }^{173}$ In July 1926, Ras Tafari sent a letter to the League, duly circulated to League members and published, contrasting his belief that "all nations were to be on a footing of equality within the League, and that their independence was to be universally respected" with the seeming reality of Anglo-Italian collusion. This did not force the withdrawal of the notes altogether, ${ }^{174}$ but caused Britain and Italy to disclaim formally any intention to "reserve" any part of Ethiopian territory. ${ }^{175}$

Historically, Ethiopian rulers had been bound by treaties which they were sometimes unable to read themselves, and European governments had exploited linguistic ambiguities in correspondence to which Ethiopian rulers had had limited access. ${ }^{176}$ League procedures ensured, at least, that the Ethiopian Government would have access to the actual texts,

\footnotetext{
${ }^{169}$ Ras Tafari to Bentinck, Jan. 26, 1926, enclosure 1 in Bentinck dispatch, Jan. 28, 1926, FO 371/11561 [J497/19/1].

${ }^{170}$ See, e.g., correspondence in FO 371/11560 [J363/19/1, J447/19/1]; FO 371/11561 [J458/19/1]; FO 371/ 11562 [J847/19/1].

${ }_{171}$ See, e.g., Graham to Chamberlain, May 7, 1926, FO 371/ [J1137/19/1].

172 Correspondence in FO 371/11562 [J1207/19/1].

${ }^{173}$ HC DEB, supra note 45, at vol. 197, col. 1614 (July 5, 1926); see also vol. 197, col. 1120 (June 30, 1926)

${ }^{174}$ Although Ethiopia could, in theory, have argued that they were contrary to the undertaking given by members under Article 20 of the Covenant that "they will not hereafter enter into any engagements inconsistent with the terms thereof."

${ }^{175}$ See correspondence published in 7 LNOJ 1524-25 (1926).

176 See, e.g., Sven Rubenson, The Protectorate Paragraph of the Wichate Treaty, 5 J. Afr. Hist. 243 (1964); Sven Rubenson, Professor Giglio, Antonelli and Article XVII of the Treaty of Wichate, 7 J. Afr. Hist. 445 (1966) (on the disputed clause in an 1889 treaty, used by Italy to claim a protectorate over Ethiopia).
} 
and could contest their terms on a footing of formal equality. On the other hand, it did not change the underlying dynamics of power relations or avert Italian expansion in the long term.

Finally, while Article 18 reflected a strategy of using law to entrench publicity, the law itself continued to complicate the underlying project. Aside from the deep structural concerns which had limited the interpretation of Article 18, diplomatic crafts of drafting and terminological subtleties central to the law of treaties had enabled officials to preserve margins for secrecy without making them obvious to legislatures and the public. Publics in the democracies surveyed here remained deeply concerned about "secret treaties" throughout the interwar period. The revelation of leaked or forged "secret treaties" produced periodic press scandals. Yet there was a diminishing sense that the public might ever discover the truth of what was occurring. Admittedly, the subtleties surrounding understandings of "treaty," "agreement," "understanding," and the like could trap officials as well as confuse publics. Sometimes instruments which were never intended to have legal force attracted suspicion, and the terminological complexity left governments unable to convey the innocent or trivial nature of the transactions at stake. Overall, though, the complexity of the vocabulary probably weakened faith that the true picture could be known, and thus dissuaded public engagement.

\section{The Drafting and Interpretation of Article 102 of the Charter, C. 1945-1949}

Although wartime conditions in 1939-45 interrupted the usual course of both international and domestic treaty publication, the United States and the United Kingdom, at least, assumed that the treaty publication requirement would be reintroduced in some form after WWII. Eleven other, mostly small, states raised the issue in their responses to the Dumbarton Oaks proposals. ${ }^{177}$ However, in 1945, general interest and faith in publicity was weaker than it had been a generation earlier. The norm of treaty publication was perhaps associated with an idealism which was seen to have failed. Moreover, the connections between multilateralism, international organization, and publicity, influential in the design of the League, were weakened in the transition to a new international organization. The Security Council was envisaged as wielding centralized military force, which would give it greater powers to police state conduct without relying on publicity, and would require the United Nations itself to maintain regimes of military and intelligence secrecy.

American officials played a decisive role in the crafting of what would become Article 102 of the Charter. ${ }^{178}$ Although figures like Hudson had been consistently supportive of the League of Nations Treaty Series, and keen that it continue in some form, American officials in San Francisco distanced themselves from the Article 18 precedent. They observed that the word "every" in "[e]very treaty or international engagement" had, "by interpretation and in practice, lost most of its significance," and that the apparent sanction of invalidity for

1773 Documents of the United Nations Conference on International Organization, San Francisco, 1945 , at $149,222-223,327,342,389,526,540,560$ (1945).

${ }^{178}$ American officials involved in the work of Sub-Committee IV/2/A: Other Legal Problems, the body tasked with drafting what would become Article 102, included Charles Fahy, Philip Jessup, and Henry Reiff (U.S. State Department), together with Manley Hudson (present in Sub-Committee IV/2/A as an informal observer, but whose views likely carried great weight because he had been so involved in U.S. policy on treaty registration). 
unregistered treaties had been "weakened," principally by the PCIJ's failure to apply it. ${ }^{179}$ More fundamentally, they believed that the sanction "probably did not achieve the original aim of suppressing agreements inconsistent with the peace of nations." 180 The State Department's legal adviser preferred not to include in the Charter any sanction for nonregistration. ${ }^{181}$

The U.S. draft, from which the Committee worked, imposed an obligation to register "treaties and international agreements": an arguably narrower class of texts than might have been caught by the reference to "international engagement" in Article 18. ${ }^{182}$ The draft listed two alternatives for the second paragraph. One was akin to the second sentence of Article 18, and the other was a provision to the effect that organs of the Organization could "disregard" unregistered treaties. Although some small states, including New Zealand and the Philippines, supported the former, a combination of the U.S. proposals, Hudson's interventions, and British support managed to champion the latter, providing that UN organs could choose to disregard unregistered treaties. ${ }^{183}$ This was similar to the Anzilotti/Drummond view of the interwar years. When others raised the difficulties involved in leaving the status of a treaty to ad hoc determination, particularly if the Council and the International Court of Justice (ICJ) took different approaches, ${ }^{184}$ Hudson intervened and expressed the fear that an absolutist provision like Article 18 would be interpreted in light of PCIJ precedent, and thus involve no sanction at all. ${ }^{185}$

Article 102 eventually provided that

Every treaty and every international agreement entered into by any Member . . . shall as soon as possible be registered with the Secretariat and published by it.

No party to any such treaty or international agreement which has not been registered ... may invoke that treaty or agreement before any organ of the United Nations.

Article 102 was, on its face, open to the same interpretive controversy as Article 18: did it impose an absolute obligation to register, or merely stipulate the consequences that would follow from a failure to do so? The first sentence of Article 102 suggested the former interpretation, but some invoked the limited sanction to suggest the latter. ${ }^{186}$ On the latter interpretation, states could create secret obligations which were legally binding inter se, provided

${ }^{179}$ ISO 165, Nov. 22, 1944, 4, 5, PCJ I:166. ["PCJ" in archival references denotes Philip C. Jessup papers, Library of Congress (Washington, DC)].

$180 \mathrm{Id}$. at 7.

${ }^{181}$ Views of [Green Haywood Hackworth], May 10, 1945, PCJ I:166.

182 US IV/2/A Doc. 5, May 18, 1945, 1, PCJ I:176. For text of Article 18, see supra note 2.

${ }^{183}$ US IV/2/A Doc. 6, May 19, 1945, 2-3, PCJ I:176.

${ }^{184} \mathrm{Id}$. at 3 and Corrigendum; US IV/2/A Doc. 7, May 21, 1945, PCJ I:176. Article 102 in fact gave rise to a host of difficulties. On a literal reading, a non-party to an unregistered treaty could invoke the treaty before the International Court of Justice (ICJ), whereas a party could not; and a party could invoke an unregistered treaty before, say, an arbitral tribunal or domestic court, but not the ICJ. See, e.g., Ernst Martens, Article 102, in 2 THE Charter of the United Nations: A Commentary 2089, 2105-06 (Bruno Simma, Daniel-Erasmus Khan, Georg Nolte, Andreas Paulus \& Nikolai Wessendorf eds., 3d ed. 2012); Michael Brandon, The Validity of Non-registered Treaties, 29 BRIT. Y.B. INT'L L. 186, 198-99 (1952).

${ }^{185}$ US IV/2/A Doc. 7, supra note 184, at 1. Jessup thought there "seem[ed] to be no satisfactory explanation" of why the PCIJ had ignored Article 18. Jessup to Fahy, May 13, 1945, 2, PCJ I:166.

186 See, e.g., Wilhelm Karl Geck, Treaties, Registration and Publication, in 7 Encyclopedia OF PUBLIC INTERNATIONAL LAW 490, 494 (Rudolf Bernhardt ed., 1984) (suggesting that "the watering down of the sanction" 
they accepted that they could not invoke these obligations in UN fora. Other aspects of the Charter drafting also weakened the Covenant's model of centralized supervision over treatymaking. ${ }^{187}$

By 1945, there had been no further clarification of the terms "treaty" or "international agreement." 188 This left a certain ambiguity about the reach of Article 102, even aside from the limited nature of the sanction. At San Francisco, the drafting committee had discussed an explicit exception for agreements between individual states and the Security Council about military forces (then envisaged as part of an international military force which never eventuated). ${ }^{189}$ However, this exception had been abandoned because it was expected that subsequent "regulations" would confine the reach of Article 102. ${ }^{190}$ The FO and State Department contemplated trying to include in the General Assembly resolution concerning implementation of Article 102 some limitation of the classes of texts requiring registration (in the FO case, by transposing some version of the exclusions identified in the Law Officers' opinion), ${ }^{191}$ but this failed, and the resolution ultimately just deferred to "experience and practice" to set its bounds. ${ }^{192}$ In an early concession to the growing role of international organizations as legal actors, that resolution did make clear that "treaty or international agreement" included agreements between UN member states and specialized agencies. The resolution also set out an alternate procedure ("filing and recording") for certain texts that were deemed not to come within Article 102, notably agreements between the $\mathrm{UN}$ and non-member states, the UN and specialized agencies inter se, and the UN or specialized agencies and other inter-governmental bodies. ${ }^{193}$

Importantly, the resolution required a party submitting a treaty for registration to certify that the text was a true and complete copy thereof and included all reservations. The UN Secretariat thus considered that "[i]t was not permissible simply to register a treaty and to withhold any

relative to what Article 18 had provided might have "contributed to a weakening of the binding power of the obligation to register").

${ }^{187}$ Article 14, the successor to the Covenant provision concerning the Assembly's power to advise reconsideration of treaties (see supra text at note 32), was given a more general ambit. Article 103 preserved the preeminence of Charter obligations over inconsistent treaty obligations. However, as with Article 20 of the Covenant (see supra text immediately following note 32), doubts about the nature and scope of the registration obligation hindered the sort of comprehensive oversight of treaty obligations needed to ensure that Charter obligations did in fact prevail over conflicting commitments.

${ }^{188}$ Note the haphazard terminology in Charter Articles 43, 57, 62(3), 102, 103, and 105(3); and ICJ Statute Articles 34(3), 35, 36, 37, 38(1)(a), and 63. For scholarly discussion, see, e.g., Michael Brandon, Analysis of the Terms "Treaty" and "International Agreement" for Purposes of Registration Under Article 102 of the United Nations Charter, 47 AJIL 49, 55-56 (1953); J. E. S. Fawcett, The Legal Character of International Agreements, 30 BRIT. Y.B. INT'L L. 381 (1953). Suggested exclusions from the term “treaty” begged more questions. Denys P. Myers, The Names and Scope of Treaties, 51 AJIL 574, 598, 600 (1957).

${ }^{189}$ US IV/2/A Doc. 7, supra note 184, at 3; Doc. 8, May 24, 1945, 2; PCIJ I:176.

${ }^{190}$ Edward R. Stettinius, Charter of the United Nations: Report to the President on the Results of the San Francisco Conference 154 (June 26, 1945); see also Foreign Office, A Commentary on the Charter of the United Nations, Cmd. 6666, para. 74 (1945).

${ }^{191}$ Minute Beckett, Nov. 7, 1946, FO 372/4847 [T21331/4751/581].

192 GA Res. 97(I) (Dec. 14, 1946), as modified by GA Res. 364 B (IV) (Dec. 1, 1949); 482 (V) (Dec. 12, 1950); 33/141 A (Dec. 18, 1978).

${ }^{193}$ See discussion in Aron Broches \& Shirley Boskey, Theory and Practice of Treaty Registration with Particular Reference to Agreements of the International Bank, in Selected Essays: World Bank, ICSID, and Other Subjects of Public and Private International Law 99, 107 (Aron Broches ed., 1995). 
confidential exchange of letters which might, in fact, modify its substance." 194 Although an analogous requirement had existed in the League Secretariat's 1920 Memorandum, it had not been made central to debates over Article 18, and the UN Secretariat's position seemed to signal a stricter approach than had been taken to texts like the Franco-Belgian military accord.

In echoes of the interwar experience, however, early compliance with Article 102 was patchy. Attempts to articulate the strongest possible reading of even the limited terms of Article 102, and to foster compliance, were hampered by institutional constraints within the Secretariat (which was unable to confront permanent members of the Security Council), and the fact that even some strong advocates of registration felt vulnerable to attack over their own past practice.

In the Sixth Committee, the USSR seized on an observation by the Committee Chair that Article 102 did not impose an absolute obligation to register, but merely outlined the consequences of not doing so (a position rejected by a number of other states, including the United States, Britain, and France). ${ }^{195}$ The FO contemplated from time to time whether Article 102 might be more energetically enforced, particularly against the USSR. ${ }^{196}$ In 1949 an official in London noted that:

after several battles in the Sixth Committee, it has been agreed to differ, and Article 102 is gradually losing its force. We do not yet say in public, however, that we are not prepared to register all agreements. . . . It could be added confidentially that we have not recently been beyond reproach ourselves. ${ }^{197}$

Britain reaffirmed its view internally that Article 102 imposed an absolute obligation to register, ${ }^{198}$ but had by this time experimented with new techniques of secrecy (outlined below), and had been implementing some troubling secret agreements, including one requiring the (sometimes forcible) repatriation of liberated Soviet citizens in the United Kingdom. ${ }^{199}$ Though this agreement predated the Charter and was thus not required to be registered, its implementation proved morally disturbing, and created difficulties under domestic law, meaning there were incentives to avoid provoking mention of it by the USSR. ${ }^{200}$

\section{Secret Treaties in the Post-1945 World}

\section{Domestic Law and Bureaucratic Practice, c. 1945-1990}

In the decades following WWII, all three states examined here continued to permit the making of treaties (in the international law sense) which remained unpublished. In the

\footnotetext{
1945 Repertory of Practice of United Nations Organs [1945-1954], at 286-87, available at http://legal. un.org/repertory/art102.shtml.

${ }^{195}$ See A/C.6/SR.54 (meeting of Oct. 29, 1947). In subsequent years Russian delegates participated in discussions in the Sixth Committee in a manner which the FO believed was a tacit admission of obligation to register. Southern Department to British Legation, Budapest, Dec. 19, 1950, FO 371/87810 [RH10338/11 1950].

196 See, e.g., Heathcote-Smith, Mar. 10, 1947, FO 372/6099 [T4383/383/381].

${ }^{197}$ Minute [Hildyard?], Jan. 9, 1949, FO 371/77445 [N11004/1138/30].

198 Southern Department to British Legation, Budapest, supra note 195.

${ }^{199}$ Copy in FO 371/57287 [U3903/1730/70]; referred to but not reproduced in 1 DocUMENTS ON BRITISH Policy Overseas (Series I) 73, n. 2 (Rohan Butler \& M. E. Pelly eds., 1984).

${ }^{200}$ See, e.g., correspondence in FO 371/47897 [N3670/409/38].
} 
United States, the experience of wartime governance, and the knowledge that the Senate's rejection of the Treaty of Versailles a generation earlier had weakened the League system, motivated arguments that the president had authority to make treaties under international law by a process other than the two-thirds majority approval of the Senate required for "treaties" within the meaning of Article II of the Constitution. ${ }^{201}$ Scholarship and jurisprudence had already recognized "executive agreements" pursuant to an existing treaty or legislation, and in exercise of the president's constitutional powers. ${ }^{202}$ Post-1945 developments would help to articulate more clearly a further variant: agreements subject to expedited approval or implementation, not by the Senate, but by a majority in both Houses, and subsequent approval by the president. ${ }^{203}$ Such "Congressional-executive" agreements, like Article II "treaties," would necessarily be subject to the publicity associated with the legislative process. Executive agreements pursuant to existing treaties or legislation, or under the president's constitutional powers, on the other hand, while usually published, could be withheld from publication. A State Department circular of 1955 clarified the Department's view of the power to make executive agreements; ${ }^{204}$ reiterated an undertaking by the secretary of state to consult with Congressional leaders and committees, if circumstances permitted, where any serious question arose as to whether a given agreement should be treated as an Article II "treaty," or as an executive agreement on one basis or another; and mandated certain notifications to and consultations with the State Department in the course of negotiations.

In the United Kingdom, the Ponsonby rule remained the only "constitutional" limit on the Crown's treaty-making powers. This rule did not apply to a large class of treaties made in a form not requiring ratification. These were sometimes laid for twenty-one days, especially where there was public interest, but not in all cases of important agreements. ${ }^{205}$ It remained the practice to publish treaties in the Treaty Series whether they were laid in Parliament or not, but this was not legally required. It was acknowledged internally that "one often finds that politically most important things are done by instruments which come into force on signature only ..."206 and governments insisted on discretion regarding the choice of form. ${ }^{207}$

${ }^{201}$ For opposing cases, see, e.g., MCClure, supra note 120; Edwin M. Borchard, American Government and Politics: Treaties and Executive Agreements, 40 Am. Pol. Scr. Rev. 729 (1946). "Executive agreements," even those grounded in the constitutional authority of the president alone, had now been held to have the same supremacy over state law as Article II treaties. United States v. Pink, 315 U.S. 203 (1942); United States v. Belmont, 301 U.S. 324 (1937).

202 See supra text at notes 119-20.

${ }^{203}$ For a detailed account, see, e.g., Ackerman and Golove, Is NAFTA Constitutional?, 108 HARv. L. REv. 799, 866-96 (with reservations as to the notion of a "constitutional moment"). On increasing recourse to the executive agreement, see Glen S. Krutz \& Jefrrey S. Peake, Treaty Politics and the Rise of Executive Agreements 3746 (2009).

${ }^{204}$ Department of State Circular No. 175, para. 3 (Dec. 13, 1955), reproduced in 50 AJIL 784 (1956). With some variation of expression, this categorization of the constitutional bases for executive agreements remains in place today. Compare Restatement (Second) of Foreign Relations Law \$\$119-21 (1965); Restatement (Third) of Foreign Relations Law $\$ 303$ (1987); 11 Foreign Affairs Manual 723.2-2(A)-(C) (rev. 2006), available at https://fam.state.gov/default.aspx\#.

${ }^{205}$ Evans and Anderson, The Presentation of Treaties to Parliament: The Ponsonby Rule, Mar. 31, 1969, FCO $53 / 81$.

${ }^{206}$ Minute Beckett, Nov. 30, 1948, FO 372/6727 [T24653/24653/381].

${ }^{207}$ HL Deb, supra note 168, at vol. 180, col. 1285 (Swinton, Mar. 11, 1953). 
As in the interwar period, focus on the Ponsonby rule may have distracted attention from the question of whether treaties not subject to ratification were published at all. ${ }^{208}$

The initial French post-war constitution preserved the requirement for legislative approval of a specific list of treaties, but removed the requirement for the president to inform the legislature of all treaties "[a]s soon as the interest and safety of the state shall permit." A 1953 decree gave the MAE exclusive responsibility (as against other government departments) for the ratification (if necessary) and publication of all "conventions, accords, protocoles et règlements internationaux" to which France was a signatory, or by which France was engaged. This decree, however, only required publication in the Journal Officiel of instruments of a nature which would affect private rights and duties. ${ }^{209}$ The 1958 Constitution distinguished between "traités" (i.e., in this context, texts subject to ratification or analogous process) and "accords internationaux" (i.e., in this context, international agreements not subject to ratification or analogous process). ${ }^{210}$ It provided, as under earlier constitutions, that the president "negotiate and ratify" traités, and be kept informed of all negotiations leading to the conclusion of an international agreement. ${ }^{211}$ Again, only a closed list of specific kinds of treaties and international agreements required legislative approval and associated publicity. Any treaty not falling within these categories, and not intended to take effect within domestic law, or affecting private rights and duties, might be kept secret by the executive indefinitely.

\section{Familiar Techniques of Secrecy in a Changing World}

In some respects, officials navigating publicity requirements after WWII were moving in a world rather different to that of the 1930s. The United States' ascendance to global influence gave the U.S. government new influence over publication practice. The UK, on the other hand, experienced a rapid decline, and sometimes sought the face-saving secrecy she had formerly bestowed on others. The United Nations played a greater role as a site of contestation over compliance than the League had done, in part because Cold War adversaries embraced the United Nations as a platform. While the Soviet government had not complied with Article 102, American celebration of democracy and openness left NATO governments vulnerable to accusations of hypocrisy for any failure to register. Overall, greater international cooperation, including the proliferation of transnational functional cooperation not

${ }^{208}$ See response to a parliamentary question in 1945, asking for an assurance that no agreement will be concluded until it has been "confirmed" by Parliament. While initial proposals for a response mentioned that the government must retain a discretion not to publish some agreements, the final answer turned on the Ponsonby rule. Minute [Robb?], Nov. 2, 1945, and final response, FO 370/1194 [L3470/3470/402].

${ }^{209}$ Decree No. 53-192, Mar. 14, 1953, [1953] Journal OfFiciel de la République FranÇAise: Lois 2436, Art. 3, available at https://www.legifrance.gouv.fr/affichTexte.do?cidTexte=JORFTEXT000000491782\& categorieLien=id. An arrêté of June 16, 1955 required the Service des Archives to maintain a record of all international engagements, of whatever nature. France resumed publication of a regular treaty series in 1958, with the RECUEIL DES TRAITÉS ET ACCORDS DE LA FRANCE, but this seems primarily to have reproduced texts already published in the Journal Officiel. A separate project to publish all bilateral treaties and accords made since 1567 and still in force, published or unpublished, was pursued in the 1970s, beginning with 1 RECUEIL GÉNÉRAL DES TRAITÉS DE LA France. 1er Série. Accords bilaterauX publiés et nOn publiés au Journal Officiel de la République FranÇaise (1564-1957) (Roger Pinto \& Henry Rollet eds., 1979).

${ }^{210}$ Constitution of Oct. 4, 1958, available at http://www.assemblee-nationale.fr/connaissance/constitution. asp.

${ }^{211}$ In practice, many "traités" (in the narrow sense-i.e., subject to ratification or analogous process) are in fact not ratified by the president, but "approved" by the government. Paul Reuter \& Philippe Cahier, Introduction AU DROIT DES TRAITÉS 78, n. 97 (3d ed. 1995). 
channeled through foreign ministries, increased the scale of treaty-making and challenged foreign ministries' institutional control over treaty-making processes (a phenomenon reflected in periodic attempts, discussed below, to reassert foreign ministry consultation and oversight).

That said, there were important continuities in the general areas in which secrecy was deemed desirable, particularly trade (especially before the advent of the General Agreement on Tariffs and Trade) and defense (where the development of atomic weapons, and the formalization of military and intelligence cooperation amid Cold War hostilities contributed to an institutionalization of bureaucratic secrecy well beyond the treaty context). ${ }^{212}$ While the scale of post-WWII decolonization would mark a major break from the interwar order, treaty relations between former colonial powers and post-colonial states, exemplified in the French case explored below, often showed an interweaving of public and secret commitments of a kind seen, for example, in interwar dealings between Britain and Iraq.

Where there was a felt need for secrecy, diplomats and officials fell back on some of the techniques seen earlier: crafting packages of texts, some for publication and some not; and maintaining ambiguity about the legal status of particular texts. Persistent questions about legal status arose in particular in connection with recourse to "inter-agency" or "inter-departmental" agreements, concluded by agencies or departments in their own name with foreign counterparts rather than in the name of the relevant governments. ${ }^{213}$ Though acknowledged earlier (for example, by the British Law Officers' reference to agreements not arranged through "diplomatic" channels"), ${ }^{214}$ these agreements proliferated after WWII, creating possibilities for secrecy, but also challenging foreign ministries' control of international commitments in ways that would ultimately demand correction.

As before, British and American officials were inclined to enforce a legalistic approach to what was required to be published, whereas French officials, when they considered registration, seem to have assumed a capacious exception for "administrative" or "technical" agreements (a posture which probably reflected pre-WWII attitudes, but also precarious control of treaty texts following the disruption of the MAE and its records under Vichy and occupation). ${ }^{215}$ In all three states, fine distinctions made internally between different kinds of text, and the nuanced deployment of treaty terminology, were not well understood by legislatures or the public.

${ }^{212}$ New systems of information classification, extended and generalized beyond the military context, do not seem to have been reconciled conceptually with requirements for treaty publication. Rather, texts arrived in foreign ministries subject to classification (if at all), and foreign ministries had to either find ways to justify their secrecy within the norms pertaining to treaty publication, or press for revision of the classification.

${ }^{213}$ A highly significant, if unique, instance was the Anglo-American "Communication Intelligence Agreement" of March 5, 1946, signed by representatives of the U.S. State-Army-Navy Communications Intelligence Board, and the London Signal Intelligence Board, each of which was said to represent multiple departments and agencies. This Agreement, and its 1955/56 successor, consolidated wartime intelligence and cryptanalysis cooperation, and laid the foundations of the "Five Eyes" program (documents available at https:/www.nsa.gov/news-features/ declassified-documents/ukusa/index.shtml).

214 See supra text at note 81.

${ }^{215}$ Efforts in the 1950s to secure submission of original agreements to the Archives Service seem to have had only mixed success. De Gaulle's discovery in the late 1950s that 1954 agreements between France and the Federal Republic of Germany had not been published in France helped "empty the drawers." La Publication des engagements internationaux de la France, 8 ANNUAIRE FRANÇAIS DE DROIT INTERNATIONAL 888, 899 (1962). In 1955 a Bureau des Traités was created within the Ministry, and the constitutional reform of 1958 prompted more regular procedures, but reminders suggest ongoing difficulties. See, e.g., correspondence in MAE Direction des Archives 289 [1720-1970. Dossier général]. 
For the United States, the key challenge in the early post-war years was reconciling Article 102 with the demands of a global military presence. The State Department resisted attempts to formulate blanket exceptions for agreements made by agencies other than foreign ministries, or dealing with defense and sensitive matters. Instead, officials held out the possibility of "distinguish[ing] between the substance of an agreement and mere administrative arrangements made ... in implementation of it," 216 albeit on the basis that the latter must not be "integral parts" of the treaty or agreement. ${ }^{217}$

The United States was willing to take the risk that secret treaties could not be invoked before the United Nations, but was concerned about exposure to criticism by the USSR. While it might be argued that Article 3 of the NATO Treaty and announcements of integrated defense forces gave " $[\mathrm{t}]$ he peoples of the world . . . notice, in broad terms, as to what is being done," and met "the "public relations' test," this did not satisfy Article 102.218

A memorandum reviewed possible techniques, and their limitations. Service-to-service agreements (a variant of the "inter-agency" agreements mentioned above) might arguably not constitute treaties or agreements captured by Article 102. However, governments and the U.S. Department of Defense "prefer the additional stability of a government-level agreement." 219 Countries might work through bilateral institutions rather than treaties, creating bodies like the United States-Canada Permanent Joint Board on Defense, which would then make plans and decisions functionally equivalent to what might otherwise be dealt with by treaty. But this depended on the states involved having close working relationships. Finally, parties could reach principal agreements in broad terms, with classified annexes. This final option was seen, at least in the U.S. defense context, as preferable. ${ }^{220}$ The United States proposed this to other key NATO powers, and even contemplated making a public announcement of this policy, a course discouraged by French officials. ${ }^{221}$ In practice, some ancillary texts would drift beyond the position prepared for Congress, namely that "not all purely technical or administrative arrangements, such as details on staffing or equipping or manner of operation of bases established in implementation of the [NATO] Treaty, are published."222

Like the State Department, the FO deemed it acceptable to keep secret a strictly delimited set of ancillary texts: "a confidential letter, or agreed minute which explains in greater detail the effect of the published document," or "embod[ies] understandings which are not

${ }^{216}$ Foster, Registration of Treaties Under Article 102 of the UN Charter, May 9, 1947, NARA RG 59, 194549 CDF, Box 2063 [501.AJ/Treaties/6-1947] ["NARA RG 59 . . CDF" in archival references denotes National Archives and Records Administration, Reading Group 59, Department of State Central Decimal File (held in Washington, DC)].

${ }^{217}$ Fahy, circular Registration of Treaties with the United Nations, June 19, 1947, NARA RG 59, 1945-49 CDF, Box 2063 [501.AJ/Treaties/6-1947].

${ }^{218}$ Registration of Defense and Base Rights Agreements with the UN, Dec. 1, 1951, NARA RG 59, 1950-54 CDF, Box 1263.

219 Id.

${ }^{220}$ US-UK agreements regarding the use of bases in the United Kingdom, however, were typically not framed as treaties. See Simon Duke, US Defence Bases in the United Kingdom: A Matter for Joint Decision? (1987) (giving history of negotiations).

${ }^{221}$ In view of the possible propaganda use which might be made of it by the USSR. Note pour le Président Schuman, Mar. 17, 1952, MAE NUOI 596 [S50.5.2] ["MAE NUOI" in archival references denotes Archives diplomatiques (France), "Nations Unies et Organisations Internationales" series (held at La Courneuve)].

${ }^{222}$ Questions and Answers" prepared in connection with hearings over the Bricker Amendment, NARA RG59 Department of State Lot Files, Lot 79 D 273, Box 5 (emphasis added). 
intended to constitute international obligations ... but ... are rather declarations of policy or of attitude." 223 Such texts were used in the defense context, sometimes in ways which strained the limits imposed by the FO. A notorious example is the secret exchange of notes between the U.S. ambassador in London and the secretary of state, accompanying the published 1967 agreement regarding U.S. rights on Diego Garcia. ${ }^{224}$ The secret exchange made arrangements for concealment of associated expenses, including for compensation of existing colonies from which the territory was taken, from both the British and American legislatures. These notes "confirm[ed]" the "financial arrangements which have been reached," by which was understood the position that the UK would meet these costs initially, and then be compensated for half of them by manipulating liabilities under an unrelated agreement concerning the Polaris missile program. ${ }^{225}$

By 1950 the FO had developed a detailed list of exclusions to the definition of treaty, and thus to the set of texts it considered necessary to submit for registration. ${ }^{226}$ Some of these exceptions, like that for unilateral statements, and for agreements operating under municipal law, were congruent with prevailing understandings of the treaty under international law (even if somewhat stretched in practice). Others, like that for minutes of standing committees composed of national representatives (a device popular with the Board of Trade, but not the FO), ${ }^{227}$ and agreements subsidiary to and not materially altering a principal agreement, ${ }^{228}$ reflected more artificial pathways for secrecy.

France seems to have been less preoccupied by the Article 102 requirement. Where secrecy was felt necessary, the government took advantage of the possibilities provided by domestic law. This is particularly evident in relations with former African colonies, including provisions, inter alia, for French intervention to maintain internal order. The felt need for secrecy in these instances may have emerged from a French desire to conceal details of military arrangements, or to avoid being pressed by other states to ratchet up support, but the main impetus for secrecy seems to have come from the new regimes' concern to preserve at least a façade of independence (or, conceivably, anxieties about possible obstacles to UN membership arising from a perceived lack of independence). ${ }^{229}$

Post-independence treaties with Cameroon offer a particularly clear example of the drafting strategies used to maintain secrecy. The suite of texts included a Treaty of Cooperation, annexing various published accords and conventions. At the same time, the same plenipotentiaries signed a secret defense accord, providing, inter alia, that the Republic of Cameroon

\footnotetext{
${ }^{223}$ Dunbar to [various government departments], July 23, 1946, FO 372/4847 [T10754/4751/381]; see also minute Beckett, Mar. 1, 1947, FO 372/6099 [T383/383/381].

${ }^{224}$ Agreement on the Availability for Defence Purposes of the British Indian Ocean Territory, 603 UNTS 273 (subsequently amended).

225 The secret exchange, which came to light in the 1970s, to heavy criticism, is reproduced in PETER H. SAND, United States and Britain in Diego Garcia: The Future of a Controversial Base 8 (2009).

${ }^{226}$ As reflected in, for example, circular Griffiths to colonial governors, Registration of International Agreements with the United Nations, May 2, 1950, FO 372/6968 [TF12/17 1950].

227 See, e.g., correspondence in FO 372/6717 [T12897/1677/381].

${ }^{228}$ For FO criticism of creative use in the trade context: minute Cox, June 28, 1948, FO 371/68917 [UE5746/ $78 / 53]$

${ }^{229}$ On Cold War-era challenges to UN admissions on the basis of lack of independence, see Ulrich Fastenrath, Article 4, in 1 The Charter of the United Nations: A Commentary 341, 344-45 (Bruno Simma, DanielErasmus Khan, Georg Nolte, Andreas Paulus \& Nikolai Wessendorf eds., 3d ed. 2012).
} 
could request France to provide, on conditions defined by further special accords, the assistance of French armed forces for the maintenance of internal order, ${ }^{230}$ together with various annexes (on aid and mutual facilities and strategic primary resources). ${ }^{231}$ Plenipotentiaries signed one protocol of ratification for all the public accords and a separate secret protocol for the defense accord. ${ }^{232}$ This was possible under both the French Constitution and the new Cameroonian constitutional framework, which referred to the making of "agreements [accords] and treaties" but provided only for "treaties" to be submitted to the National Assembly for approval prior to ratification. ${ }^{233}$ Texts forming part of the same cluster of transactions were thus sorted, by form and terminology, into public and secret. ${ }^{234}$

Most of the post-1945 secret treaties and ancillary texts described thus far reflect a gradual systematization of a secrecy that could be cultivated within and through law, or at least in the complex relations between the law of treaties, and the diplomatic crafts of drafting. Yet there were also instances of radically irregular "secret treaties," like the "Protocol of Sèvres" (1956), ${ }^{235}$ settled outside the usual machinery of foreign policymaking and envisaging conduct in breach of international law. ${ }^{236}$ The Protocol was in part a response to Nasser's nationalization of the Suez Canal, and an effort to check Nasser himself, who was thought to be a conduit of Soviet influence in the Arab world. It provided for an Israeli attack on Nasser's Egypt, following which Britain and France, ostensibly onlookers to the operation, would issue appeals to both sides to withdraw troops from the Canal zone, and press Egypt to accept temporary occupation by Anglo-French forces. ${ }^{237}$ The Protocol was, in substance, a secret offensive alliance, one of the very phenomena that proponents of publicity had aspired to eliminate.

${ }^{230}$ This echoed earlier, short-term secret agreements made pre-independence, and used for operations against the "Union des Populations du Cameroun," a dynamic and transnationally active resistance movement which sought the unification of French and British Cameroon before independence. See Meredith Terretta, Nation of Outlaws, State of Violence: Nationalism, Grassfields Tradition, and State Building in Cameroon 2-11 (2014).

${ }^{231}$ Note pour le Service du Protocole, Dec. 22, 1960, both in MAE Afrique-Levant 1953-1959/Cameroun/10 [Accords franco-camerounais 1960-62] [hereinafter MAE Cameroun 10]. The "accord de défense" was sometimes characterized as a secret annex to the Treaty of Cooperation, and sometimes as freestanding. The final text is now available at http://www.diplomatie.gouv.fr/traites/affichetraite.do?accord=TRA19600199.

232 Benart to MAE, Nov. 16, 1961, in MAE Cameroun 10, supra note 231.

233 The French understanding was that the secret defense accord could be ratified without Parliamentary approval under the Cameroonian Constitution because it was not a "treaty" within the meaning of the constitutional text, although internal French correspondence refers to an article which does not seem to bear directly on the question. Note a/s. Instruments de ratification des accords franco-camerounais du 13 novembre 1960, Jan. 12, 1961, MAE Cameroun 10, supra note 231.

${ }^{234}$ This and subsequent texts were treated as classified. Tibault StÉPHÈne Possio, Les Évolutions RÉCENTES DE LA COOPÉRATION MILITAIRE FRANÇAISE EN AFriQue 150, 429-433 (2007) (on subsequent texts).

${ }^{235}$ Reproduction of French original and English translation in S. Ilan Troen, The Protocol of Sèvres: British/ French/Israeli Collusion Against Egypt, 1956, 1 IsR. STUD. 122, 131 (1996). The originals were headed "Protocole" and "Protocol" respectively, and "Sèvres," the location of its signature, was added to many subsequent references.

236 The British Lord Chancellor had advised that the intervention was a lawful defense of British nationals and property (without commenting on the significance of the deception involved in its arrangement), but the attorneygeneral and FO legal advisers, not consulted in advance about the plan reflected in the Protocol, disagreed after the fact. On the exchange of legal views as the situation developed, see Geoffrey Marston, Armed Intervention in the 1956 Suez Canal Crisis: The Legal Advice Tendered to the British Government, 37 InT'L \& ComP. L. Q. 773 (1988).

237 See also a further Franco-Israeli agreement regarding air defenses in Troen, supra note 235, at 135. 
On one view, the secrecy of the Protocol was tangential, as the nefariousness of its contents placed it outside the register of law altogether. There is an inherent contradiction in appealing to law to hold other parties to an undertaking to behave unlawfully. Translated into doctrinal terms, one might argue that there could not have been, in the circumstances, an intention to create legal relations at all. ${ }^{238}$ That said, there are indications that at least some of the signatories considered the Protocol to have legal force. The text, drafted by French and Israeli officials, had characteristics reminiscent of a treaty. Drafters had intended for it to have a preamble, but ran out of time to craft one. The text was signed by representatives of the parties, and referred to the fact that its provisions would enter into force ["entreront en vigueur"] after the agreement of the three governments (the delay being occasioned by the fact that the British signatory was a deputy under-secretary of state, who could only sign ad referendum). ${ }^{239}$ Israeli negotiators, who had requested preparation of the document, were keen for the political and symbolic prestige associated with signing a formal document of some kind (even in secret) as an equal with major powers; ${ }^{240}$ and the French signatory, in his memoirs, did not exclude the notion that the Protocol was intended to have legal force. ${ }^{241}$ Subsequent letters confirmed the French and Israeli governments' agreement to both "the result of the conversations of Sèvres and the terms of the final protocol to which they gave rise," 242 giving the Protocol a status independent of the conversations. The British prime minister, by contrast, was dismayed that the Protocol had been brought into existence at all, and tried to suppress all material trace of it. ${ }^{243}$

We might see this behavior as reflecting the ubiquity of legal forms. Even where parties considered themselves to be making, at best, a "non-binding agreement," they drifted by habit and training into forms characteristic of a treaty. Alternatively, it might speak to the endurance among some diplomats and statesmen of a radically voluntarist model of international law, in which states' agreements inter se are thought to have some legal force despite being at odds with other undertakings, not least the UN Charter. To the extent this is the

${ }^{238}$ The later progressive development of the law in VCLT, Article 53, concerning a treaty in conflict with a peremptory norm, such as the prohibition of aggression, offers a different possibility for some such cases: there may have been a treaty, but one that was void ab initio. However, this position remains controversial, and may still not have attained customary status.

239 Christian Pineau, 1956 Suez 152-53 (1976).

${ }^{240}$ Keith Kyle, Suez 326, 330 (1991); Avi Shlaim, The Protocol of Sèvres, 1956: Anatomy of a War Plot, 73 InT'L AfF. 509, 522, 529 (1997). That said, a desire for a formal document is not in itself a belief that the document was legally binding.

${ }^{241} \mathrm{He}$ observed later that it was an exaggeration to call the text a "treaty," and that it was rather a "temporary agreement relating to a specific action" ["accord temporaire portant sur une action précise"], following completion of which the engagements have no further purpose. However, this observation does not exclude a supposition that he believed it to be legally binding as far as it went. PINEAU, supra note 239, at 149 .

${ }^{242}$ Mollet to Ben-Gurion, reproduced from Ben-Gurion Archives in Troen, supra note 235, at 136.

243 Requesting, unsuccessfully, that the French destroy their copy, and having all copies in British hands destroyed (Meetings at Sèvres 22-25 October 1956, Narrative, Donald Logan (24 October 1986), FCO 12/ 183; Meeting with Sir Donald Logan on Suez Records, 15 April 1986, FCO 12/178). Eden's letter following the Protocol signing confirmed only that the British would "take the action described" in the Sèvres conversations, making no reference to the Protocol text (Eden to Mollet, as reproduced in Troen, supra note 235, at 137). The earlier written "declaration" by Eden to which reference is made in this letter has not been traced in British archives. Jonathan Pearson, Sir Anthony Eden and the Suez Crisis: Reluctant Gamble 150-151, 222, n. 43 (2003). 
case, it highlights starkly the terrain left open once a failure to register (and thence have published) a treaty was deemed not fatal, in itself, to its legally binding status.

\section{New Trends in the Management of Secrecy, c. 1960s Onward}

The law of treaties underwent major scrutiny in the 1950s-60s, culminating in 1969 with the VCLT. However, the codification process had relatively limited impact on publication. Crucially, the VCLT preserved the ambiguities over the outer bounds of the category of treaty which had been so central to the accommodation of secrecy. ${ }^{244}$ In stipulating the limited extent to which a failure to respect provisions of internal law, including requirements that treaties be laid before legislatures or published beforehand, might be invoked to invalidate consent, it left open the possibility that secret treaties might bind states even in circumstances where they had been made in violation of domestic law. ${ }^{245}$

From the late 1960s, however, there were a number of changes to the management of secrecy in the three states surveyed here, driven primarily by democratic concerns and functional imperatives linked to the growing scale of treaty-making. This part sketches three such changes: (1) requirements for provision to the U.S. Congress of (and thus publicity for) executive agreements, some of which had escaped Congressional attention to date; coupled with public acknowledgement of the existence of a category of "classified agreements," to be supplied only to House and Senate committees under injunction of secrecy; (2) efforts to grapple with the legal status of inter-agency agreements; and (3) formalization and elaboration of the genre of the "non-binding agreement." Avenues (1) and (2) further systematized a margin for secret, yet legally binding, texts, continuing the dual history of entrenchment of a norm of publication alongside preservation of possibilities of secrecy. Avenue (3) pushed secret arrangements out of the realm of legal obligations altogether, thus fulfilling the spirit of Article 18, but not in a way which definitively resolved the boundary between "treaties" and "non-binding agreements."

As the "vast sub-structure of intergovernmental paper" grew after WWII, the difficulty of distinguishing treaties from mere diplomatic correspondence became more acute. ${ }^{246}$ Congressional hearings in the late 1960s over contested issues of foreign policy brought to light that major allocations of funds and materiel, as well as representations about how the United States would conduct itself in particular contingencies, rested not only on Article II "treaties," but rather on executive agreements of various kinds, including oral statements. While State Department officials were well-versed in diplomatic wording that conveyed

${ }^{244}$ See, e.g., Jean d'Aspremont, Formalism Versus Flexibility in the Law of Treaties, in ReSEARCH HaNDBOOK ON THE LaW of Treaties 257, 261-74 (Christian J. Tams, Antonios Tzanakopoulos \& Andreas Zimmermann eds., 2014). Lingering questions about the outer bounds of "treaty" are evident in the scholarship. See, e.g., Michel Virally, Sur la notion d'accord, in FestsChrift FÜr Rudolf BindsCHEdler 159 (Rudolf Bindschedler, Emanuel Diez, Jörg Paul Müller, Heinrich Reimann \& Luzius Wildhaber eds., 1980); Kelvin Widdows, What Is an Agreement in International Law?, 50 BRIT. Y.B. INT'L L. 117 (1979); Pierre Michel Eisemann, Le Gentleman's agreement comme source du droit international, 106 JOURNAL DU DROIT INTERNATIONAL 326 (1979).

245 VCLT, supra note 3, Art. 46.

246 The phrase is from R. R. Baxter, International Law in “Her Infinite Variety," 29 INT'L \& ComP. L. Q. 549 , $556(1980)$ 
distinctions between executive agreements and lesser texts, Congressional committees did not necessarily grasp these nuances, and nor did foreign governments. ${ }^{247}$

Congressional concern about unchecked executive power over foreign policy spurred the Case-Zablocki Act of 1972, which required "any international agreement, other than [an Article II] treaty" to be reported to Congress within sixty days of entry into force. ${ }^{248}$ Any agreement "the immediate public disclosure of which would, in the opinion of the President, be prejudicial to . . . national security" was to be transmitted only to House and Senate Committees on Foreign Relations under injunction of secrecy. ${ }^{249}$ The State Department interpreted the Act as further qualified by an inherent executive privilege which might permit the withholding of an otherwise reportable agreement. ${ }^{250}$ However, the Act did acknowledge the existence of classified executive agreements-secret treaties, in the international law sense-and provide limited Congressional oversight. In the United Kingdom and France, there was no equivalent explicit acknowledgement and, to the extent that secret texts were available to legislatures, this occurred, in all likelihood, only on an ad hoc basis.

In the United States, efforts to implement the Case-Zablocki Act led to a reckoning with "inter-agency agreements." Scholarly commentary had expressed doubts about the extent to which such agreements could bind the state, at least independently of some principal text made in the name of heads of state or government. ${ }^{251}$ In the United States, agencies did not always supply the texts of agreements to the State Department in a timely way, or at all. ${ }^{252}$ Recourse to such agreements thus undermined both Congressional oversight under the Case-Zablocki Act, and the ability of the State Department to exercise centralized control over U.S. commitments. In 1976, the State Department clarified that it regarded "agency level agreements" as capable of binding the United States under international law, and as

${ }^{247}$ See, e.g., negotiations with Spain 1969-70 for U.S. base rights, complicated by suspicion and misunderstanding of prior transactions. Hearings before the Subcommittee on United States Security Agreements and Commitments Abroad of the Committee on Foreign Relations, United States Senate, 91 Cong., Part 11 (Mar. 11, Apr. 14, 1969; July 17, 1970) 2309-2311, 2322, 2388, 2342 (Evidence of Elliot Richardson) (1970).

${ }^{248}$ Pub. L. 92-403, \$1, 86 Stat. 619 (Aug. 22, 1972), later reflected in 1 U.S.C. $\$ 112$ b (1982 comp.). This was subject to an agreed exclusion for "trivia."

${ }^{249}$ An interview in June 1974 with a senior staff member of the House Foreign Affairs Committee indicated that $5-10 \%$ of all "international commitments" (primarily those dealing with military policy) were classified. Loch K. Johnson, The Making of International Agreements. Congress Confronts the Executive 28, n. 11 (1984).

250 Abshire to Weinberger, Aug. 18, 1972, NARA RG 59, Box 1959 [POL 4].

251 See, e.g., Basdevant, supra note 21, at 624-25; Herbert Kraus, Système et fonctions des traités internationaux, 50 R.C.A.D.I. 311, 328-29, 352-54, 368 (1934); J. Mervyn Jones, International Agreements Other Than "InterState Treaties"-Modern Developments, 21 BRIT. Y.B. InT'L L. 111 (1944); J. L. Weinstein, Exchanges of Notes, 29

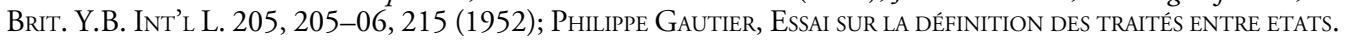

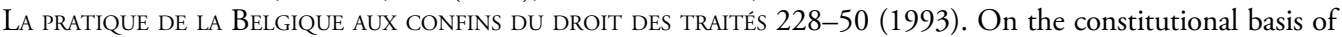
"agency level agreements" in the United States, see David J. Kuchenbecker, Agency-Level Executive Agreements: A New Era in U.S. Treaty Practice, 18 Colum. J. Transnat'L L. 1, 21-31 (1979). Although the UK position accepted that departments could bind the state, it tended to see these agreements as limited to transactions of a private law character (which would not be treaties in any event). ARnOld DunCAn MCNair, The LAW of TrEaties 20-21 (1961).

${ }^{252}$ Comptroller-General of the United States, U.S. Agreements with the Republic of Korea, ID-76-20 (Feb. 20, 1976); Hearings before the Subcommittee on International Security and Scientific Affairs of the Committee on International Relations, House of Representatives, 94 Cong. (June 22, 23, 29, 30; July 20, 22, 1976) 237-240 (responses by the Hon. Monroe Leigh) (1976). 
falling within the Case-Zablocki Act as long as they met certain criteria. ${ }^{253}$ The Act was modified in 1977 and 1978 to require all agencies to transmit agreements to the State Department within twenty days, with oral agreements to be reduced to writing and reported; and to consult with the State Department consultation, at least over certain categories of agreement, before signature. ${ }^{254}$ The State Department position on what was captured by the Act, and the obligations of other agencies, were incorporated in regulations in 1981, albeit subject to a stipulation that failure to comply with the regulation did not affect the validity of an agreement in domestic or international law. ${ }^{255}$

In France, too, the perceived need for the foreign ministry to reassert control over increasingly dispersed transnational cooperation seems to have driven the adoption of circulars in the 1980s requiring that all persons signing international engagements have instruments of full powers, and that, once signed, texts be sent to the MAE. ${ }^{256}$ In the United Kingdom, although there had been discussion, for example, of the capacity of bodies like the Bank of England to enter into agreements with counterparts, the preference appears to have been to treat many "inter-agency" agreements as non-binding, and thus separate to some extent from the treaties for which the Foreign and Commonwealth Office was administratively responsible. ${ }^{257}$

If new developments on legislative oversight in the United States, and bureaucratic disciplines on inter-agency agreements, tended to formalize possibilities for secret yet legally binding commitments, recourse to "non-binding agreements" offered an alternate means of securing secrecy (along with other benefits, like simplicity of negotiation and amendment). Such "non-binding agreements" were, in one sense, merely a continuation of nineteenthcentury "gentlemen's agreements." However, the latter tended to be expressed in brief and sometimes personal terms, and rest on the honor of individual diplomats, whereas post-WWII arrangements could be lengthy and detailed, and purport to engage agencies, governments and the state rather than individuals. ${ }^{258}$ While non-binding agreements could be used for high-profile "political" commitments like the Helsinki Final Act, ${ }^{259}$ in which case they might be widely published, and even reproduced in collections of legal materials, they were of particular utility where states wished to avoid the publication requirements associated with treaties. ${ }^{260}$

By the 1970s-80s, British practice and scholarship had developed a fine-grained account of the textual and other indicators differentiating a non-binding agreement (which came

${ }^{253}$ Were intended to be legally binding and governed by international law; were not trivial; were between two or more parties; contained obligations of some degree of specificity; and were of a form to indicate an intention to be legally bound. Memo Monroe Leigh to Key Department Personnel, Mar. 12, 1976, reproduced in id., 240-43.

${ }^{254}$ Pub. L. 95-45, \$5, 91 Stat. 224 (June 15, 1977); Pub. L. 95-426, Title VII, \$708, 92 Stat. 993 (Oct. 7, 1978); reflected in 1 U.S.C. $\$ 112 b$ (1982 comp.).

25546 FR 35918, July 13, 1981, as amended; see 22 C.F.R. $\$ 181.1(b)$.

256 The circulars exempted "administrative arrangements which do not engage the State and bind only the administrations concerned," though it is unclear how administrative departments alone could have the capacity to enter into binding arrangements. Geneviève Burdeau, Les Engagements internationaux de la France et les exigences de l'Etat de droit, 32 ANNUAIRE FRANÇAIS DE DROIT INTERNATIONAL 837, 843 (1986).

${ }^{257}$ On the British preference for memoranda of understanding (MOUs), see infra at note 261 and following text.

${ }^{258}$ Eisemann, supra note 244, 327-31.

${ }^{259}$ Final Act of the Conference for Security and Co-operation in Europe, Aug. 1, 1975, 14 ILM 1292 (1975).

${ }^{260}$ An early account of MOUs is Anthony Aust, The Theory and Practice of Informal International Instruments, 35 INT’L \& CoMp. L. Q. 787 (1986). 
gradually to be labeled "memorandum of understanding" or "MOU”) from a legally binding treaty. Recourse to non-binding agreements appears to have been embraced in Britain and the Commonwealth even for arrangements which other states preferred to make in treaties. ${ }^{261}$ However, the distinction between a treaty and a non-binding agreement has not always been clear, even among signatories. The British contention, in a major arbitration, that an intergovernmental MOU was not legally binding ${ }^{262}$ seems to have surprised the U.S. government, and brought to the surface the fact that at least some of the MOUs which the United States regarded as treaties (in the international law sense) were not considered as such by the United Kingdom and Commonwealth states. ${ }^{263}$ There may still be instances in which the U.S. and UK governments take different positions on the status of particular texts. ${ }^{264}$ Whether this is an oversight or a tacit Atlantic "agreement to disagree" about legal status in certain problematic cases, it confirms again the porous and negotiable outer bounds of the "treaty" category.

\section{The Secret Treaty Today}

Today, Article 102 is considered to have customary status, and the Secretariat interprets "[e]very treaty and . . international agreement" as any "written agreement governed by international law entered into by parties with the requisite treaty-making capacity." 265 However, practice suggests that states consider Article 102 to be something less than a comprehensive

${ }^{261}$ For example, for the United States, demands of domestic statutory authorizations and appropriation processes, protection of private rights, and some additional prudential preference seems to have meant a desire to cast defense arrangements in legally binding terms where the United Kingdom was content to have them non-binding. John H. McNeill, International Agreements: Recent U.S.-UK Practice Concerning the Memorandum of Understanding, 88 AJIL 821, 823 (1994). France, too, has generally opposed the notion of engagements entered into by governments and yet not legally binding. SECRÉTARIAT GÉNÉRAL du GOUVERNEMENT \& ConSEIL D'ÉTAT, GUIDE POUR L'ÉLABORATION DES TEXTES LÉGISLATIFS ET RÉGLEMENTAIRES 429-30 (version of Sept. 25, 2015), available at http://www.guide-legistique.fr/guide.pdf.

${ }^{262}$ United States-United Kingdom Arbitration Concerning Heathrow Airport User Charges (1992-1994), 24 U.N.R.I.A.A. $1,131$.

${ }^{263}$ McNeill, supra note 261, at 822; Jean-Pierre Plouffe, Les Arrangements internationaux des agences et ministères du Canada, 21 CAN. Y.B. INT'L L. 176, 186-90 (1983).

${ }^{264}$ In the defense area, divergences were reconciled to some extent by the drafting of legally binding "chapeau agreements" in the 1990s, which would overlay non-binding MOUs (e.g., Defense Cooperation Arrangements Agreement, May 27, 1993, 1792 UNTS 145, 147). See AusT, supra note 7, at 39. The 2016 edition of "Treaties in Force" carried a statement that "in order to avoid confusion as to their legal character, this edition omits a number of non-binding instruments regarding defense cooperation that have been included in prior editions," but still lists under the "Defense" category an exchange of letters relating to the safeguarding of classified information (Apr. 4, 1961). See U.S. Department of State, Treaties in Force: A List of Treaties and Other International Agreements of the United States in Force on January 1, 2016, at i, 459 (2016), available at https://www. state.gov/documents/organization/267489.pdf. This exchange of letters is considered not legally binding by the UK government (communication to author from Treaty Section, Legal Directorate, FCO, June 23, 2017).

${ }^{265}$ Repertory of Practice of United Nations Organs, Supplement No. 9, at 7, available at http://legal.un.org/ repertory/art 102.shtml. As part of work on "Strengthening and Coordinating United Nations Rule of Law Activities," the secretary-general was asked by the General Assembly in 2016 to review the regulations giving effect to Article 102. He recommended, inter alia, that the Sixth Committee consider revisions, including a review of the substantive conditions for registration (but did not propose any particular approach). See Strengthening and Coordinating United Nations Rule of Law Activities: Report of the Secretary-General, para. 25, A/71/169 (July 20, 2016). The Sixth Committee has proposed to take note of the recommendations. General Assembly, Sixth Committee, Draft Resolution: The Rule of Law at the National and International Levels, para. 8(b), A/C.6/71/L.27 (Nov. 7, 2016). 
obligation to register all such texts. ${ }^{266}$ A stipulation that a given text is not to be registered may be an indication that the text is not a treaty, but this is not determinative; and the non-submission of a text for registration cannot be presumed to preclude it being a treaty. The ICJ has rendered decisions based on interpretations of unregistered treaties. ${ }^{267}$ Even as many aspects of international law and interstate interaction are subject to greater transparency, a central mode of generating legal rights and obligations in the international system remains free of any comprehensive publication requirement.

Dominant interpretations of Article 102, together with the limited attention to enforcement, mean that domestic law requirements and bureaucratic pathways probably remain the strongest determinants of publication. Domestic law requirements have strengthened since the early twentieth century, but in ways that preserve possibilities for secrecy-albeit refined and limited over time. Of the three states considered here, the United States is most forthright in asserting the existence of a category of secret treaties, in the form of "classified agreements." Article II treaties, and most executive agreements, are published or at least made publicly available, ${ }^{268}$ and thence submitted for registration. "Classified agreements," or classified ancillary texts to published agreements, are not published or submitted for registration, but are provided to the foreign relations committees of the Senate and House (unless deemed subject to executive privilege). ${ }^{269}$

France occupies a middle ground, insofar as there is a requirement to publish all treaties and agreements, but one that acknowledges some instances in which this will not be possible. Certain categories of treaty are required by the 1958 Constitution to be submitted to the legislature. An amended version of the 1953 decree still requires publication in the Journal

${ }^{266}$ Based on figures given in the Supplements to the Repertory of Practice (available at http://legal.un.org/repertory/art 102.shtml), the number of treaties submitted for registration by states has climbed from roughly 5,000 in 1960-69, to roughly 8,000 in 2000-09, but this is not remotely equal to the total number of treaties and international agreements made. It seems likely that much of the non-compliance is due to bureaucratic incapacity in state ministries, but in some cases states appear to be operating on a principle of registering only, or mostly, treaties they consider to be of particular importance. In many cases treaties are registered after significant delay, indicating perhaps declassification or correction of oversights, or anticipation that the government may wish to invoke a treaty before a UN organ. The overall rate of registration, judging very roughly from the experience of compilers of Rohn's World Treaty Index, is probably about 50\%. Glenda J. Pearson, Rohn's World Treaty Index: Its Past and Future, 29 InT'L J. LEGAL INFo. 543, 546-47 (2001).

${ }^{267}$ In several cases (Corfu Channel, Asylum, Minquiers and Ecrehos, Monetary Gold, and Anglo-Iranian Oil) the ICJ referred to unregistered treaties without mentioning Article 102 (although the texts concerned had been made public in some form). See Broches and Boskey, supra note 193, at 130-144, 152-153. In Case Concerning Maritime Delimitation and Territorial Questions Between Qatar and Bahrain, Jurisdiction and Admissibility, 1994 ICJ REP. 112, the jurisdiction of the ICJ was said by Qatar to rest on a 1987 exchange of letters, which both parties considered constituted "an international agreement with binding force in their mutual relations," and minutes of a meeting in 1990, which Bahrain contended were merely a record of negotiations, and Qatar contended rose to the level of a treaty. The ICJ held that non-registration or late registration did not warrant an inference that there was no intention to create legal relations, and did not refer to the fact that the 1987 exchange had not been registered. However, India is now seeking to argue that non-registration of a purported treaty precludes its invocation before the ICJ. See Jadhav Case (India v. Pak.), Verbatim Record of Oral Argument, paras. 16, 66(b) (Int'l. Ct. Justice May 15, 2017), available at http://www.icj-cij.org/files/case-related/168/16820170515-ORA-01-00-BI.pdf.

${ }^{268}$ Since 1994, the secretary of state has been permitted to determine that publication in the TIAS of certain categories of agreement (other than Article II treaties) is not required, if the public interest in such agreements is insufficient to justify their publication. In all instances except national security, the secretary of state must provide copies of the agreements on request under 1 U.S.C. $\$ 112 \mathrm{a}$.

26911 Foreign AfFairs Manual 725.2 (rev. 2006), available at https://fam.state.gov/default.aspx\#. 
Officiel only of treaties of a nature which would affect private rights and duties, ${ }^{270}$ though a circular of May 30, 1997 provides that, other than in exceptional cases, all accords must be published in the Journal Officiel. ${ }^{271}$

In the United Kingdom, a statutory crystallization of the Ponsonby rule, introduced in 2010, now requires that treaties subject to ratification or some equivalent procedure be laid before Parliament for twenty-one sitting days, and published in a manner that the relevant minister deems appropriate, prior to ratification. ${ }^{272}$ The publication of treaties not requiring ratification or some analogous process is governed by a convention that all such treaties be published and laid once they have entered into force. ${ }^{273}$ This issue received only glancing attention in the recent legislative reform process. ${ }^{274}$ The government makes occasional references to confidential material in treaties or ancillary texts, but often instead frames unpublished commitments as non-binding MOUs. In light of ongoing uncertainty about how to distinguish between binding treaties and non-binding agreements, and what factors will be given most weight, ${ }^{275}$ use of MOUs entails close attention to both textual indicia $^{276}$ and negotiating strategies. ${ }^{277}$

The three democracies examined here are outliers. They are unusually committed to publicity of treaties relative to states as a whole. Although numbers of treaties submitted to the UN Secretariat for registration do not indicate the proportion of treaties made by each submitter which are registered, these numbers do still give some rough sense of engagement with the Article 102 obligation. The United States is orders of magnitude ahead of other states in terms of the number of treaties submitted. The United Kingdom and France (the latter since

\footnotetext{
270 See supra note 209; current version of decree available at https://www.legifrance.gouv.fr/affichTexte.do? cidTexte=JORFTEXT000000491782\&dateTexte=20170809. The decree was amended by Decree No 86-707 of Apr. 11, 1986 to incorporate additional requirements regarding publication of reservations, interpretive declarations and denunciations. Burdeau, supra note 256, at 852-55.

${ }^{271}$ Circulaire du 30 mai 1997 relative à l'élaboration et à la conclusion des accords internationaux, [1997] Journal Officiel de la République FrançAISE 8415, available at https://www.legifrance.gouv.fr/affichTexte. do?cidTexte=JORFTEXT000000200416; see also MAE Protocole/Direction JuridiQue/Direction Des ArChives, ACCords et traités de la France de la néGociation à la Fin de validité 51 (June 2005) (on file with author).

${ }^{272}$ Constitutional Reform and Governance Act 2010 (UK), s. 20. These requirements may be overridden on a minister's initiative, subject to the treaty being laid and published as soon as possible after ratification. Id., s. 22. They do not apply to a specific list of treaties, including some which require express approval of Parliament, and others of a more routine nature (e.g., double taxation conventions). Id., s. 23. Additional requirements apply to some EU treaties. EU (Amendment) Act 2008; EU Act 2011.

${ }^{273}$ Communication to author from Treaty Section, Legal Directorate, FCO, July 16, 2015.

${ }^{274}$ House of Commons Library, Constitutional Reform and Governance Bill, 24-25 (Research Paper 09/73, Oct. 6, 2009), available at http://researchbriefings.parliament.uk/ResearchBriefing/Summary/RP09-73.

${ }^{275}$ On the ICJ's fluid approach to considerations such as textual indicia, circumstances of negotiation, domestic law concerning treaty-making powers, and the (subjective) intention of negotiators, see Chinkin, supra note 7. On indicia relevant to the determination of whether a given text is legally binding, see ROBERT KOLB, THE LAW OF Treaties: AN INTRODUCTION 19-20 (2016).

${ }^{276}$ FCO, Legal Directorate, Treaty Section, Treaties and Memoranda of Understanding (MOUs). Guidance on Practice and Procedures (2d ed., updated Mar. 2014), available at https://www.gov.uk/government/uploads/ system/uploads/attachment_data/file/293976/Treaties_and_MoU_Guidance.pdf. Cf. State Department guidance of a similar nature, at http://www.state.gov/s/l/treaty/guidance.

${ }^{277}$ In scholarly writing, a former FCO Deputy Legal Adviser has suggested that potential disagreements as to status might be headed off with a letter following the conclusion of the MOU. Anthony Aust, Alternatives to Treaty-Making: MOUs as Political Commitments, in The Oxford Guide to Treaties 46, 53 (Duncan B. Hollis ed., 2012).
} 
the mid-1960s at least) are also, in relative terms, steady submitters. Other major powers have submitted relatively few treaties. The number of treaties submitted by the Russian Federation, for example, is actually lower than under the USSR, and the Peoples' Republic of China, admitted to membership in 1971, submitted no treaties until 1985, when it began a modest rate of submission. ${ }^{278}$ Moreover, in many states, domestic law allows governments leeway to make treaties without the legislative approval or notification which is a major impetus for publication in the states surveyed here. ${ }^{279}$

For obvious reasons, it is difficult to describe secret treaties currently in force. Some of the secret treaties examined here have been replaced over time. Many early base rights agreements have now been renegotiated, for example, as have many of France's relations with former colonies. ${ }^{280}$ Where secret treaties, or secret ancillary texts, remain, they may take a more systematic and detailed form than equivalent treaties in the nineteenth and early twentieth century, commensurate with the increasing functional specialization of transnational relations. Taking the United States as an example, it is clear that some classified agreements currently in force are iterations of a known genre (such as status of forces agreements, agreements concerning base rights, or older "security of information" agreements). ${ }^{281}$ Others, however, might be rather unique arrangements. There is said to be a government-to-government agreement between the United States and Pakistan, providing for approval of at least some drone targets by Pakistani military and intelligence officials. ${ }^{282}$ There seem also to have been written arrangements in relation to at least some of the "black sites" controlled by the CIA and used for the detention, interrogation and torture of "High Value Detainees" after September 11, 2001.283 The circumstances surrounding the drafting of these texts remain unknown at this stage. It seems difficult to conceive that the "black site" arrangements, in particular, could have been intended to be legally binding, yet they were apparently intended to produce some legal effect, however attenuated, by managing the relation between legally dubious activity and the public law framework in which this activity might be assessed.

This snapshot of the secret treaty today must also acknowledge the changing role of treaties in the larger landscape of interstate interaction. Recourse to MOUs, and the proliferation of

\footnotetext{
278 These figures can be gleaned from searches by "Submittor" of the United Nations Treaty Series database, at https://treaties.un.org/pages/AdvanceSearch.aspx?tab=UNTS\&clang=_en.

${ }^{279}$ See survey in Duncan B. Hollis, A Comparative Approach to Treaty Law and Practice, in National TrEATY LaW and Practice 1, 23-38 (Duncan B. Hollis, Merrit R. Blakeslee \& L. Benjamin Ederington eds., 2005).

280 See, e.g., DÉFENSE ET SÉCURITÉ NATIONALE: LE LIVRE BLANC 154 (2008), available at http://www.ladocumentationfrancaise.fr/rapports-publics/084000341.

${ }^{281}$ For more on secret commitments, albeit not focusing on whether these are legally binding, see Deeks, supra note 5 .

${ }^{282}$ Michael Hirsh, Pakistan Signed Secret 'Protocol' Allowing Drones, NAT'L Journal (Oct. 23, 2013), at http:// www.nationaljournal.com/white-house/pakistan-signed-secret-protocol-allowing-drones-20131023.

283 See, e.g., Affidavit of Józef Pinior (reporting being informed of a "document drawn up under the auspices of the government of Leszek Miller for the purpose of regulating the existence of the CIA prison in Poland ... [containing] precise regulations concerning the foundation of the CIA secret prison ... [and] propos[ing] a protocol for action in the event of a prisoner's death"); and evidence of Mr. JGS [adviser to Senator Marty] (making reference to "authorising agreements, which granted extraordinary protections and permissions to the CIA in its execution of detainee operations"), as quoted in Husayn (Abu Zubaydah) v. Poland, Judgment, paras. 297, 323 (Eur. Ct. H.R. July 24, 2014), at http://hudoc.echr.coe.int/eng\#\{"itemid":["001-146047"]\}; see also Dick MarTy, SECRET Detentions and Illegal Transfers of Detainees Involving Council of Europe Member States: Second REPORT, at paras. 176-77, 211, 219-20 (June 11, 2007), available at https://assembly.coe.int/Documents/ WorkingDocs/2007/edoc11302.htm (on arrangements with authorities in host states).
} 
international organizations, may be moving whole domains of activity out of the realm of treaty governance altogether. While international organizations' own treaty-making has been subject to the norm of treaty publication, ${ }^{284}$ such organizations also offer an alternative means of coordinating action. Matters which might once have been agreed in a treaty may now take the form of an internal decision, resolution, or policy of an organization or network - and escape the norm of publication applicable to treaties altogether. ${ }^{285}$

\section{The Survival of the Secret Treaty: Past and Future}

The history traced here reveals contrasting trends. On one hand, the development of an international norm of treaty publication strengthened domestic publication processes. It brought into being a centralized (and now digitized, and freely accessible) repository of treaties, featuring authenticated texts and translations, thereby enabling tangible instantiations of treaty law as a genuinely international corpus. It created a dynamic in which one state's publication was a matter of legitimate concern to, and discussion in, other states, and made it impossible for democracies which wished to uphold the values of the League and United Nations to assert baldly that they were making secret treaties. That said, the relationship between publicity and legality sketched first in Article 18 of the Covenant has never been wholly realized, either in international law or the domestic law of leading democracies.

Even if democracies make relatively few secret treaties, the overall workings of treaty-making offer a contrast with the hopes of 1919. Reformists of the early twentieth century had envisaged registration and resulting publicity as marking off a realm of legally binding treaties from other possible commitments, grounded in honor or interest, but without legal force. This vision has been seriously compromised. The secret treaty remains a viable legal instrument in many states, hindered only by an uneven patchwork of domestic law. In the states surveyed here, foreign ministries have accepted that published treaties may have secret ancillary texts, the relation of which to the principal text is policed with varying degrees of strictness. Secret commitments may be channeled outside the register of law altogether, into MOUs. Such MOUs may constitute a law-like corpus of obligations, even while not formally legally binding. They exist in a sort of parallel system that may not be superior, on rule of law or practical grounds, to secret but legally binding treaties. Moreover, secret texts-whether framed as ancillary to the published treaty or as MOUs not having legal force themselvesmay well shape the interpretation of published texts, creating stratifications of knowledge about putatively public transactions.

The gulf between the state of affairs today and the hopes of reformers in 1919 is partly the result of short-term interests of governments and institutions pressing against the norm of publication and the ideals it was intended to serve. But the history also suggests significant complications in the reformists' vision. If it might broadly be conceded that publicity of treaties assisted in democratic control of foreign policy, it became clear that publicity alone was insufficient. Meaningful review of treaties required a more sophisticated institutional machinery for legislative oversight (something reflected in changing structures and practices in the

\footnotetext{
${ }^{284}$ See supra at note 193; Vienna Convention on the Law of Treaties Between States and International Organizations or Between International Organizations, Art. 81, UN Doc. A/CONF.129/15 (Mar. 21, 1986).

285 This shift intersects also with the rise of "informal law-making." See, e.g., Informal InTERNATIONAL LaWmaking (Joost Pauwelyn, Ramses A. Wessel \& Jan Wouters eds., 2012).
} 
legislatures of many states since WWII). The notion that a norm of publication would foster peace, too, was challenged, with secrecy about interstate financial dealings seen as potentially fostering peace and stability. Some of the secrecy intended to mask humiliating inequalities of negotiating power between states might also be understood as upholding peaceful avenues for interstate interaction. Even with military arrangements, views about the genesis of conflict shifted, such that secrecy came to seem not a catalyst for suspicion and belligerence but a necessary element of the defense of the existing order. The complexity of any relation between publicity and peaceful relations, or at least the avoidance of aggression, is borne out by post1945 game-theoretical and strategic approaches to the role of information in the shaping of state behavior.

As for the imagined relationship between publicity and legality, the basic intuition animating Article 18 - that legal obligations are, or should be, intrinsically public — was countered by the persistence, alongside increasing institutionalization of international law, of a voluntarist understanding in which states themselves retained discretion about the forms of their legal obligations inter se, and the disclosure of these obligations.

The relationship between the norm of publication, and the general construction of a law-governed international order, proved similarly conflicted. On one hand, the forging of a centralized corpus of treaty law, and the improvement of national publication practice, seems likely to have disseminated and help systematize international law. Moreover, the fact that secret treaties were sometimes used to coordinate unlawful, or legally dubious, actions which could not have been agreed publicly does support the intuition that a norm of publication would tend to bolster the commitment to legality in interstate relations (and, conversely, that violation of the norm of publication would tend to undermine legality). Yet many secret treaties do not anticipate a violation of law. Secret treaties of this kind may reflect, in a perverse way, faith in the power of legal obligations to guide behavior, even in the absence of the mechanisms for institutional vindication of rights, and reputational pressure, which usually accompany (public) treaty obligations. Episodes like the 1926 dealings with Ethiopia do suggest that the norm of publication sometimes fostered a more inclusive, open interstate interaction, vindicating sovereign equality, instead of perpetuating hierarchical, self-selecting clubs. However, the history given here suggests that a norm of treaty publication may not displace power politics even from the limited domain of treaty-making, but rather transpose it onto new procedural terrain, favoring parties best able to manipulate the subtleties of drafting.

Law itself proved resistant to reordering in favor of publicity and double-edged as an instrument of transformation toward greater publicity. Legal advisers were often among those who upheld strong readings of publicity requirements, and tried to entrench them in bureaucratic practice. Yet the law was not a neutral instrument. Not only was the deep structure of the law of treaties resistant to a universal norm of publication, the law of treaties both accommodated, and obscured from public view, the preservation of secrecy in more quotidian ways. The uncertainties about the outer bounds of the category of "treaty," coupled with the diplomatic craft of drafting layered and fragmented arrangements, offered avenues for secrecy. These avenues only multiplied as the scale and extent of treaty-making grew, testing the institutional capacities of foreign ministries and legislatures. The technical complexity of the law meant that the persistence of secrecy was often opaque to the very legislatures and publics thought to be empowered by publicity. More generally, the transmutation of political opposition to 
"secret treaties" into a specific legal discourse steered contestation over the limits of publicity into highly technical legal vocabularies, and sapped much of the political impetus and public engagement which had initially animated Article 18.

The foregoing may seem a dismaying conclusion. Not only has legal reform failed to eliminate secrecy, but law has in some ways helped sustain secrecy, and legal vocabularies have deflected public scrutiny and engagement. However, the historical account provided here does not suggest that the ideals initially underpinning Article 18 ought to be abandoned, or that they are unattainable. Rather, this history invites new research into the incidence of secrecy in treaty-making, its effects and implications-but with a more sophisticated understanding than was available in 1919 of the architecture of publicity and secrecy, and the economies of knowledge to which it gives rise.

This historical account suggests the importance of domestic law and bureaucratic processes of treaty-making in shaping responses to the norm of publication. Secrecy may be permitted by domestic law, or negotiated in the interstices of publication requirements, through some of the techniques illuminated here. This article has focused on leading liberal democracies. The global incidence of secret treaties, and current motivations for secrecy, especially in the relations of autocratic or illiberal states, remain to be explored. Secret treaties may be more prevalent in illiberal states than among democracies (although, paradoxically, difficulty in making credible commitments may require such states to use public and enforceable agreements on points of importance). There remain also interesting questions about patterns of secrecy in dealings between more and less open states. In many of the interactions surveyed here, the liberal democracy has been the more powerful or influential interlocutor, but where roles are reversed, or two states relatively evenly matched, will the publication practices of democratic states prevail, despite preferences for secrecy among less open interlocutors?

Analysis of the effects of secrecy must take account of the complexity of secrecy as a phenomenon. Texts are not always sorted into binary categories of "secret" and "published," but arranged into larger transactional complexes. There is sometimes ambiguity, or disagreement between the parties, about the legal status of particular texts. Secrecy is not an "all or nothing" quality. It sometimes entails strict controls on flows of information, and sometimes a much looser arrangement, which does little to prevent information leaking out, but relieves governments of the need to detail, or admit, a state of affairs which is widely understood. Particular commitments might be entirely unknown to the public, known in their general lines but not their specificities, or well-known only to certain segmented audiences (for example, foreign intelligence services).

Once understood in this light, secrecy might have diverse consequences. In circumstances where even published treaties are proliferating at a rate that challenges the capacity of sophisticated bureaucracies, ${ }^{286}$ secrecy may affect the likelihood of a treaty ever being fulfilled. In other words, some connection between registration and publication, on one hand, and binding force, on the other, may operate in practical terms. Conversely, provided a secret text is known to relevant personnel, it might shape official actions despite not being processed by foreign ministries or included in the corpus of published commitments. Secrecy may have

\footnotetext{
286 See, e.g., Department of State, Office of Inspector General, Memorandum Inspection Report. Review of Treaty Management Responsibilities in the Office of Treaty Affairs, Report No. ISP-C-05-01, at 2 (Dec. 2004), available at https://oig.state.gov/system/files/146709.pdf.
} 
implications for the way in which international commitments can be invoked in domestic law, and thus the state's ability to implement undertakings, or to justify its conduct. Secrecy may also play an enduring role in the interpretation and evolution of commitments over time. Where secret commitments are present, the interpretive process is necessarily opaque (even more so than it might be in the case where travaux préparatoires and other material pertinent to interpretation are not widely distributed). This may favor the position of the more powerful party, although dynamics in particular instances will vary enormously. ${ }^{287}$ All of this suggests that the effects of secrecy in particular cases depend greatly on the institutions and regimes involved, the stratifications of knowledge among different sets of interlocutors, and the dynamics of the substance of the treaty.

Analysis of secrecy's instrumental effects does not exhaust the intellectual challenge it poses. Secrecy is not only a subject of study in its own right, but a revealing window onto some larger questions. To return to the theme of the relationship between publicity and legality, attention to secrecy calls into question what law is. In stripping legal obligation of its institutional and rhetorical accoutrements, it offers glimpses into-often contradictory and inchoate- understandings of the nature of legal obligation. It also sharpens normative questions about what law should be. Effects of secrecy on, for example, the coherence of the law, or of the state as a juridical actor, may be limited by strong centralized oversight of commitments that maintains coherence (or at least non-contradiction) between obligations despite the secrecy of some texts. But even in such cases, the possibility of secrecy would still call into question, for example, the very notion of international law as a knowable corpus of rights and obligations. In this respect, attention to the aberrant cases of secrecy has the potential to probe exactly what it is about lawful ordering that we find normatively compelling.

287 See, e.g., MALLARD, supra note 9 (tracing uses of "transparency," "ambiguity," and "opacity” in treaty drafting and interpretation); Avner Cohen, Worst-Kept Secret: Israel's Bargain with the Bomb (2010). 